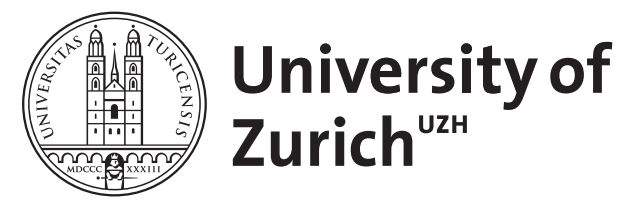

\title{
On triple auxiliation in Romance
}

\author{
Loporcaro, M
}

\begin{abstract}
Romance languages divide into three classes, as far as perfective auxiliation is concerned: as well as languages showing a binary contrast (e.g., French) and languages showing no contrast (e.g., Spanish), several varieties exist in which auxiliation displays three-way choices. Previous research on Romance auxiliaries has failed to recognize this empirical fact due to its focus on auxiliaries as morpho-lexical items, rather than on auxiliation as a syntactic phenomenon. Building on the approach to Romance auxiliation of Perlmutter (1989), this article proposes an analysis of triple auxiliation systems, as well as of systems which display variation in auxiliation, either free or sensitive to verb person. The rise of these mixed systems, like all other recorded changes in Romance auxiliation, is interpreted as one of the manifestations of the retreat of Proto-Romance active/inactive alignment and of the shift back to a more consistent accusative/nominative orientation.
\end{abstract}

DOI: https://doi.org/10.1515/LING.2007.005

Posted at the Zurich Open Repository and Archive, University of Zurich

ZORA URL: https://doi.org/10.5167/uzh-33626

Journal Article

Published Version

Originally published at:

Loporcaro, M (2007). On triple auxiliation in Romance. Linguistics, 45(1):173-222.

DOI: https://doi.org/10.1515/LING.2007.005 


\section{On triple auxiliation in Romance*}

MICHELE LOPORCARO

\section{Abstract}

Romance languages divide into three classes, as far as perfective auxiliation is concerned: as well as languages showing a binary contrast (e.g., French) and languages showing no contrast (e.g., Spanish), several varieties exist in which auxiliation displays three-way choices. Previous research on Romance auxiliaries has failed to recognize this empirical fact due to its focus on auxiliaries as morpho-lexical items, rather than on auxiliation as a syntactic phenomenon. Building on the approach to Romance auxiliation of Perlmutter (1989), this article proposes an analysis of triple auxiliation systems, as well as of systems which display variation in auxiliation, either free or sensitive to verb person. The rise of these mixed systems, like all other recorded changes in Romance auxiliation, is interpreted as one of the manifestations of the retreat of Proto-Romance active/inactive alignment and of the shift back to a more consistent accusative/nominative orientation.

\section{Introduction}

It is currently assumed that perfective auxiliary selection in Romance can either display a binary contrast (henceforth abbreviated 2-aux), as in French (auxiliaries 'have' [1a] vs. 'be' [1b] in complementary distribution) or not show any contrast at all (henceforth 1-aux), as in Spanish ([2a][2b]): auxiliary 'have' throughout):

(1) a. Marie a mangé (la soupe)

M. has eaten (the soup)

'M. has eaten (the soup).'

b. Marie est arrivée

M. is arrived

'M. has arrived.' 
(2) a. Pilar ha comido (la sopa)

'P. has eaten (the soup).'

b. Pilar ha llegado

'P. has arrived.'

In this article, I will show that this description only covers the standard Romance languages, whereas a number of nonstandard (Italo-)Romance varieties display a three-way contrast in perfective auxiliation.

This empirical point has theoretical consequences. I will show that the very recognition of the existence of triple auxiliation systems henceforth 3-aux - as well as their appropriate analysis crucially depend on the theoretical approach to auxiliation that is chosen. This is in turn a function of general assumptions in syntactic theory. The dominant view, both in traditional Romance linguistics and in current research in formal syntax and linguistic typology, takes what I term a "lexical approach" to auxiliary selection (Section 1.1). I will show that the prevalence of this view largely explains why triple auxiliation systems have gone unnoticed so far. In Section 1.2 an alternative approach is outlined, which I term the "syntactic approach" to auxiliation, as developed over the past two decades in a line of research originating from Perlmutter's (1989) analysis of auxiliary selection in Italian within the framework of Relational Grammar. In Section 2 it is shown that this approach permits a better understanding of the synchronic working and diachronic modifications of Romance auxiliation in the crosslinguistic perspective of the typology of alignment.

Once these theoretical premises have been laid, Section 3 expands the empirical database, describing different patterns of auxiliary verb variation in Italo-Romance (free or conditioned by verb person) that are unknown in the standard languages. This is needed since triple auxiliation dialects turn out to be a subset of the dialects displaying one or the other of these patterns of variation. In Section 4, I propose an inventory of auxiliary selection options observed in Romance languages and dialects which do not have variation in auxiliary choice. These options, it is claimed, form an implicational scale. Section 5 shows that mixed auxiliation systems naturally fit onto this independently established scale, and Section 6 finally turns to the analysis of triple auxiliation systems, demonstrating that they are constrained by the same hierarchy. Section 7 summarizes the results, spells out the implications of this study for syntactic theory and places 3-aux systems within the typological perspective sketched in Section $2 .^{1}$ 


\section{Two approaches to auxiliary selection}

The study of perfective auxiliaries is a traditional topic in Romance linguistics (cf. e.g., Berchem 1973), and one that has been explored in depth in modern research in formal syntax as well as in linguistic typology. ${ }^{2}$ In spite of this, looking through recent literature on the topic, one soon runs up against a paradox. On the one hand, everybody agrees that a perfective auxiliary contributes grammatical rather than lexical meaning to a compound verb form. Thus, in the Italian compound perfect ha cantato 's/he has sung' the auxiliary is a tense/aspect/mood (= TAM) and person marker, in the same way as is the inflection $-a$ in the present canta 's/he sings'. The auxiliary contributes finite verb morphology, not lexical information, the latter being conveyed by the verb stem of what is aptly called the lexical predicate.

On the other hand, crosslinguistic study of auxiliary selection not only in functionally oriented linguistics but also in formal syntax seems to concentrate on properties of the lexical items have and be in order to explain the syntactic distribution of auxiliaries. In the functionalist camp, typological work on grammaticalization of auxiliaries (Harris and Ramat 1987; Heine 1993; Kuteva 2001) basically focuses on the paths (semantic bleaching etc.) that lead to a lexical predicate becoming an auxiliary over time. Synchronically too, the main focus is on the relationship of auxiliaries to other verbs of the language ("full predicates"), including typically those otherwise (or previously) meaning 'hold', 'have', 'be' etc.

This kind of approach I will call the "lexical approach to auxiliary selection": a first exemplification is provided in Section 1.1 (cf. also Section 3.2 for further examples and discussion).

\subsection{The lexical approach}

Consider the much-quoted study of Romance auxiliary selection by Lois (1990) (followed by Kempchinsky 1996 and others). The explanandum is the different distribution of the auxiliary 'have' in modern Spanish (cf. [2]), where it is generalized to all predicates, vs. French (cf. [1]) and Old Spanish, where auxiliary 'have' occurs with transitives and unergatives, but does not combine with unaccusatives. ${ }^{3}$ The basics of Lois' proposal are summarized in the next example:

(3) a. habere ${ }_{1}=$ Fr. avoir, O.Sp. haber

[+Object Case]

$[+$ subject $\theta$-role $]$ 
b. habere $_{2}=\mathrm{Sp}$. haber

[-Object Case]

[u subject $\theta$-role]

The explanation proposed starts from the observation that the outcome of Latin habere has ceased to be used as possessive verb in Spanish. This means, according to Lois, that the lexical item haber changed its lexical specification as shown in (3). It used to be marked [+Object Case] and [+subject $\theta$-role], which means that it was transitive in Old Spanish and remained transitive in French (3a), but it has lost both properties in modern Spanish (as shown in [3b]), where it became incapable of assigning Object Case and became $\mathrm{u}(\mathrm{nmarked})$ for subject $\theta$-role. ${ }^{4}$ This change in lexical specification allegedly made it possible for haber to be assigned as perfective auxiliary to unaccusatives too.

This explanation suffers from empirical inadequacy, as there are many Romance varieties in which the implications established by Lois do not hold. Consider for instance the Calabrian dialect of Trebisacce (data from Pace 1993-1994: 75, fn. 17, 129, 136): ${ }^{5}$
a. ağğə na ka:sə nu ma:rə
have.1sg a house in-the sea
'I've got a house at the seaside.'
b. marí a mmort
Mary has died.fsg

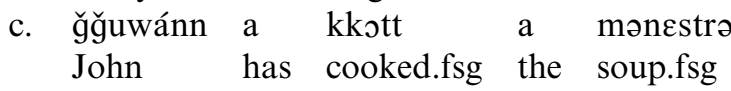

In Trebisacce, possessive 'have' is preserved (4a), unlike in Spanish; nevertheless, 'have' did spread as a unique auxiliary, also to unaccusatives, just like in Spanish (4b). Furthermore, past participle (henceforth PtP) agreement is preserved (4b)-(4c), unlike in Spanish, which contradicts Lois' predictions. Given the feature specification of auxiliary 'have' assumed for Romance varieties in which this auxiliary was generalised (3b), it should have lost the ability to assign Object Case, which in turn should have resulted in the impossibility for PtP to agree with the direct object.

Thus, Lois' account is indeed an ad hoc formalization of the Spanish facts, but it is of little use as soon as we expand the database beyond the seven or eight Romance standard languages and consider the dozens of sister languages traditionally called "Romance dialects".

\subsection{The syntactic approach}

The alternative approach to be followed in this article has been developed in a line of research started by David Perlmutter in the early 1970s 
and developed further in Rosen (1988, 1990, 1997) and La Fauci (1988, 2000). Within this framework an auxiliary is defined as follows:

(5) Auxiliary

"Auxiliaries are a lexically designated closed class of verbs whose defining property is that they inherit a $1 . "[1=$ subject $]$

(Rosen 1997: 112)

From this formal definition, all remaining properties of auxiliaries usually listed in typological surveys follow automatically:

(6) a. an AUX must have the same Subject as the uninflected dependent verb;

b. $V_{\text {fin }}$ and $V_{\text {inf }}$ must have the same PRED(icate) frame (= argument grid);

c. no semantic restrictions are imposed by the AUX $\left(\mathrm{V}_{\text {fin }}\right)$ on the $\mathrm{V}_{\text {inf }}$;

d. AUX expresses TAM relations.

(Ramat 1987: 13)

The first property (6a), corresponding to Rosen's formalization in (5), is the fundamental one: a predicate that does not introduce a new subject into the clause (unlike causatives, for instance) has no argumental grid at all. Hence, it has no lexical semantics of its own and only conveys TAM relations (6d), much like inflectional endings in finite verb forms (cf. Section 1). Thus, under definition (5), an auxiliary is a syntactic object whose distribution has to be characterized exclusively in terms of syntactic structure, without reference to the lexicon and, especially, to lexical semantics (e.g., $\theta$-roles, contra the approach in Section 1.1).

In case there is an alternation, the auxiliary fulfils the syntactic function of signaling a contrast between different clause types. This is the case in French (seen above in [1]) or Italian (cf. [7]), while in languages without alternation, such as Spanish (2) or Catalan (8) (as well as in Portuguese and Romanian), this function is not (any longer) fulfilled by auxiliaries:

(7) a. transitive/unergative

Maria ha mangiato (la minestra)

M. has eaten (the soup)

b. unaccusative

Maria è arrivata

M. is arrived.fsg

(8) a. transitive/unergative

l'Antonia ha menjat (la sopa)

A. has eaten (the soup) 
b. unaccusative
l'Antonia ha anat al cine
A. has gone to-the cinema

The contrast in auxiliation in (7a) and (7b) is one of the empirical correlates of Perlmutter's (1978) Unaccusative Hypothesis (henceforth UH), developed in the framework of Relational Grammar (henceforth RG). As is well known, the UH classifies (monadic) intransitive predicates into two subclasses, distinguished by the grammatical relation they assign to their respective nuclear argument. This is shown in the structural representations in (9a) and (9b), which incorporate Davies and Rosen's (1988) theory of clause union (grammatical relations are expressed through the following conventions: $1=$ subject, $2=$ direct object, $3=$ indirect object, $\mathrm{P}=$ predicate, $\mathrm{Cho}=$ chômeur, i.e. "the relation held by a nominal that has been ousted from term status", Blake 1990: 2): ${ }^{6}$

(9)

\begin{tabular}{|c|c|c|}
\hline 1 & & $\mathrm{P}$ \\
\hline 1 & $\mathrm{P}$ & Cho \\
\hline Maria & ha & telefonatc \\
\hline 'Mary & has & phoned.' \\
\hline 2 & & $\mathrm{P}$ \\
\hline 1 & & $\mathrm{P}$ \\
\hline 1 & $P$ & Cho \\
\hline Maria & è & arrivata \\
\hline 'Mary & has & arrived.' \\
\hline
\end{tabular}

Unlike the argument of unergatives (9a), that of unaccusative predicates is an initial direct object and becomes the final subject of the clause through $2 \rightarrow 1$ advancement (9b). ${ }^{7}$ Given (9a) and (9b), both 'have' and 'be' satisfy the formal definition of auxiliary in (5). For their complementary distribution, a straightforward generalization becomes available (revised from Perlmutter 1989: 82):

(10) Auxiliary selection (Italian):

Auxiliary essere 'be' if the final 1 is a 2 in the clause.

Auxiliary avere 'have' elsewhere.

This generalization also covers the contrast in perfective auxiliation between plain vs. reflexive transitives:

\begin{tabular}{|c|c|c|c|}
\hline 1 & & $\mathrm{P}$ & 2 \\
\hline 1 & $\mathrm{P}$ & Cho & 2 \\
\hline Maria & ha & lavato & la macchina \\
\hline
\end{tabular}




\begin{tabular}{cccc} 
b. & 1,2 & & $\mathrm{P}$ \\
1 & & $\mathrm{P}$ & \\
\hline 1 & $\mathrm{P}$ & Cho & \\
Maria & si è & lavata & \\
'Mary & has & washed & herself.'
\end{tabular}

Representation (11b) is based on Rosen's $(1982,1988)$ account of Romance reflexives, defined as clauses whose final subject bears both the 1 and 2 relations at some stratum. This multiattachment is then resolved $(1,2 \rightarrow 1)$ before the final stratum, a process that correlates with the occurrence of the clitic $s i .^{8}$

Summing up, conceiving auxiliaries as purely syntactic objects, as formally defined in (5), paves the way for a straightforward account of auxiliary selection in Italian. This extends naturally to the whole of Romance, in both a synchronic and diachronic perspective.

\section{Romance auxiliation in typological perspective}

Auxiliary selection, while being one of the correlates of the UH in Italian or French, need not be so in every (Romance) language. The fact that Spanish, Catalan, Portuguese, Sicilian, etc. have generalized one auxiliary only means that auxiliary selection ceased to be sensitive to the structural contrasts in (9a)-(9b) and (11a)-(11b), and not that unaccusative predicates ceased to exist in these languages, unlike what is implied by some scholars:

Nous utilisons l'auxiliaire être comme diagnostique pour l'inaccusativité. [...] les langues comme l'espagnol n'ont donc pas de verbes inaccusatifs (Bessler 1995: 283, Note 6).

These languages, in fact, still display a number of syntactic features that are amenable to simple formalization only under the assumption that the structural contrast unaccusative vs. unergative ([9a] vs. [9b]) was preserved in spite of the change in auxiliation. ${ }^{9}$ The list includes, among others, PtP agreement and "partitive" cliticization in Catalan; the syntax of participial absolutes, which are grammatical with unaccusatives and ungrammatical with unergatives in all Romance languages (including Catalan, Spanish and Portuguese); the syntax of Ibero-Romance impersonals, which allow for bare nouns to occur postverbally with unaccusatives only (cf. Alsina 1996: 105-108; Loporcaro 1998: 217-218). ${ }^{10}$

Moreover, historical evidence shows that condition (10) must have been at work in Proto-Romance and that the contrast observed between 
the two groups of Romance languages in (1)/(7) vs. (2)/(8) arose later. Apart from Romanian, where the generalization of a avea was already accomplished by the time of the earliest extant documents, Spanish and Catalan - as well as other 1-aux varieties like Portuguese or Sicilian show a more limited distribution of the outcome of Lat. habere in Medieval texts, a distribution which basically coincides with the one found today in Italian. Consequently, the Italian distribution as stated in (10) can be assumed to directly mirror the original situation in ProtoRomance. ${ }^{11}$

The change 2-aux $>1$-aux, which made auxiliation insensitive to unaccusativity, was part of a larger diachronic process that must be understood in a typological perspective. As argued in La Fauci (1988), one of the major syntactic transformations that distinguished Proto-Romance (and early Romance languages) from classical Latin was the emergence of properties that contradicted the accusative/nominative alignment dominant in Latin. All of the unaccusativity effects mentioned so far, largely unknown in Latin, correspond to the active/inactive alignment type. ${ }^{12}$ For auxiliation, this can be schematically represented as follows: (from [12] onward, $\mathrm{H}$ (for habere) and $\mathrm{E}$ (for esse) will be used as abbreviations for the outcomes of the respective Latin verbs that occur as auxiliaries in the Romance varieties surveyed.)

\begin{tabular}{l||c|c|}
\cline { 3 - 3 } & \multicolumn{1}{|c|}{ inactive } & active \\
\cline { 2 - 3 } & unaccusative & unergative transitive \\
\cline { 2 - 3 } a. Italian & $\mathrm{E}$ & \multicolumn{2}{|c|}{$\mathrm{H}$} \\
\cline { 2 - 3 } b. Spanish & & \multicolumn{2}{|c|}{} \\
\cline { 2 - 3 } &
\end{tabular}

The contrast observed in Italian is binary because a subset of intransitives, viz. unergatives, shows the same behavior as transitives. (In no Romance variety do transitives and unergatives diverge in auxiliary choice.) This binary contrast (in Italian and, arguably, in Proto-Romance) is an instance of active/inactive alignment, as observed in many other language families. Consider the following examples from Basque) and Albanian:

(13) Basque

a. active

gizonak kurritu du

man-sg.act run have-3sg.act

'the man ran' 
b. inactive

gizona etorri da

man-sg.ina come be-3sg.ina

'the man came'

(Levin 1989: 57)

(14) Albanian

a. active

Agroni ka shkruar (një letër)

A. has written (a letter)

'Agroni has written (a letter).'

b. inactive

Agroni është afruar

A. is approached

'Agroni has come closer.'

(Hubbard 1985: chaps. 2-3)

Basque has active/inactive alignment not only in auxiliation (ukan 'have', $3 \mathrm{sg} d u$ in [13a], vs. izan 'be', $3 \mathrm{sg} d a$ in [13b]) but also in case marking on nominals and cross-referencing on the verb as well as in a number of other syntactic rules, such as the formation of participial adjectives (cf. Mejías-Bikandi 1990: 271-272) or the expression of partitive objects under negation through "zerik" (or "norik") inflection, discussed in Levin (1989: 45-48) and Alba Salas (2002). ${ }^{13}$ Albanian, on the other hand, has accusative alignment in (finite) verb agreement conflicting with active alignment in auxiliation.

In early Romance, likewise, the series of active/inactive morphosyntactic properties (e.g., auxiliation, PtP agreement, ne-pronominalization, the syntax of causatives) conflicted with the many accusative/nominative features that were either inherited from Latin (cross-referencing on finite verbs, case marking on personal pronouns) or established anew (SV(O) word order). ${ }^{14}$ In this conflict, La Fauci (1988) identified the reason for the well-known drift leading to the gradual fading of PtP agreement and spreading of 1-aux systems throughout Romance. This drift produced a new shift in alignment, through which Proto-Romance active/inactive features were increasingly eroded, giving way to a revival of accusative alignment.

The place of Italo-Romance 3-aux systems in this overall picture has never been discussed so far, since the systems themselves were not identified as such. After demonstrating their existence (Section 6), we will see in Section 7 that the rise of 3-aux systems also fits well into this typologically inspired account of Romance diachronic syntax. 


\section{Romance variation in auxiliaries: beyond the standard languages}

In the paradigm of Romance compound tenses one finds either only auxiliary 'have', or (more rarely, like in some Italian or Catalan dialects) only 'be', or both. While other lexical items are occasionally observed to occur as perfective auxiliaries, like in Portuguese where the outcome of Lat. tenere 'hold' eventually ousted that of habere (cf. Huber 1933: 221), one never finds within one and the same system, e.g., 'be', 'have' and 'hold'. Under the lexical approach, then, auxiliary selection is predicted to be maximally binary.

On the contrary, the syntactic approach outlined in Section 1.2 claims that auxiliation systems should not be defined in terms of the morphemes fulfilling auxiliary function but rather in syntactic terms, based on the contrasts between the clause types auxiliaries convey (e.g., unaccusative vs. unergative/transitive). Clearly, binary choice seems to be the default pattern: beside the preference for binarism in human language, a binary distinction in auxiliation is instrumental to signaling active/inactive alignment. But in spite of these cognitive and structural factors favoring binarity, under the syntactic approach there is no absolute constraint to the effect that auxiliation necessarily has to be maximally binary. Since there are more than two clause types, there is in principle structural room for ternary contrasts as well. To see how ternary contrasts can be implemented empirically, we first have to introduce some information concerning dialect variation in Italo-Romance.

\subsection{Free variation and person-related alternation of aux in Italo-Romance}

In many Italian dialects the choice of aux 'have' or 'be' is sensitive to verb person. Consider the data in (15), which illustrate the paradigm of compound perfect in the dialect of Acquafondata (Frosinone province, southern Lazio): ${ }^{15}$

(15) Acquafondata

unergative/transitive/unaccusative
1sg i so ffatəca:tə/kkwottə Kə krapittə/ i:tə
I am worked/ roasted the kid/ gone
po lle:nə
for firewood
'I've worked/roasted the kid/gone to gather firewood.'16


2sg tu si ffatəca:tə/kkwottə Kə krapittə/iitə pə lle:nə E

3 sg issə a fatəca:tə/kwottə Kə krapittə/ittə pə lle:nə $\mathrm{H}$

$1 \mathrm{pl}$ nu se:mə fatəca:tə/kwottə Кə krapittə/ittə pə lle:nə E

$2 \mathrm{pl}$ vu se:tə fatəca:tə/kwottə Kə krapittə/i:tə pə lle:nə E

$3 \mathrm{pl}$ issə a:və/annə fatəca:tə/kwottə Kə krapittə/i:tə pə lle:nə

$\mathrm{H}^{17}$

As indicated by capitals $\mathrm{E} / \mathrm{H}$ on the right-hand side, in this dialect 'have' is selected in third persons singular and plural, whereas 'be' is selected elsewhere, an alternation found in all clause types.

In many dialects of Italy, free variation of aux $\mathrm{E} / \mathrm{H}$ is also found, as illustrated in (16) with data from the Apulian variety of Altamura (Bari province): (Data are limited to 1st and 2nd persons for reasons that will become apparent below; cf. [42]-[44].)

(16) Altamura

transitive/unergative unaccusative

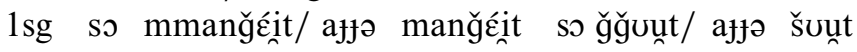
am eaten/ have eaten am gone/ have gone

(la past)

'I've gone.'

(the pasta)

$\mathrm{E} / \mathrm{H}$

'I've eaten (pasta).'

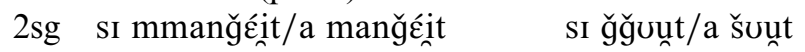
(la past)

$\mathrm{E} / \mathrm{H}$

$1 \mathrm{pl}$ asımə manğéit/amə manğع́î asımə šuunt/amə šuu్nt (la past)

$2 \mathrm{pl}$ asitə manğéit/avitə manğéit asitə šuư⿱t/avitə šuu్ (la past)

In all clause types, the auxiliaries $\mathrm{H} / \mathrm{E}$ can be selected freely, without any accompanying semantic or syntactic difference. Intermixing of $\mathrm{H} / \mathrm{E}$ across the paradigm is reported for many dialects in many areas of Italy (especially, but not exclusively, in central-southern Italy). The reference grammar of Italian dialects (Rohlfs 1966-1969: 122-126) hints at this fuzzy situation, and a first inventory of the variation observed is provided in Tuttle (1986); cf. also, more recently, La Fauci and Loporcaro (1989), Lorenzetti (1992, 1995), Loporcaro (1999, 2001), Bentley and Eythórsson (2001), Cennamo (2001), among others.

\subsection{Mixed auxiliation in the lexical approach}

Much recent work on mixed auxiliation, in a line of research inspired by Kayne (1993), has explored the possibility of deriving mixed distributions 
from structural properties inherent in the auxiliary itself (cf. e.g., Cocchi 1995; Ledgeway 1998; Manzini and Savoia 1998). The spirit of Kayne's (1993) analysis is condensed in the following quotation:

There is no auxiliary selection rule. 'Have' is identical to 'be' but for the incorporation of an abstract preposition (Kayne 1993: 3).

This idea, which elaborates on Benveniste (1960), translates formally into the structure in (17), where the abstract aux BE is postulated as underlying all surface instances of auxiliaries:

\section{(17) $\mathrm{BE} \quad \mathrm{D} / \mathrm{P}^{\circ}$ AGRs $\mathrm{T}$ AGRo (Kayne 1993: 18)}

Taking this perspective, it becomes possible to derive mixed paradigms such as those considered above in (15)-(16) along the following lines:

Following the analysis suggested above for unaccusatives, let us say that in (60) [= La Maria la s'ha vestia 'Mary has dressed herself', Trentino; M.L.] la Maria has moved through Spec,AGRo, and then directly to Spec,DP (allowable as a result of AGRs having raised to $\mathrm{D} / \mathrm{P}^{\circ}$ ). Subsequently, la Maria raises to Spec, $\mathrm{BE}$ and $\mathrm{D} / \mathrm{P}^{\circ}$ incorporates to $\mathrm{BE}$, yielding HAVE (Kayne 1993: 21). ${ }^{18}$

\subsection{Constraining empirical variation in mixed systems}

As argued in Loporcaro (2001: 460-461), this analysis boils down to a relabeling of the explanandum: whenever the auxiliary surfaces as 'be', it is assumed that no incorporation of the abstract preposition $\mathrm{D} / \mathrm{P}^{\circ}$ took place; conversely, whenever the auxiliary surfaces as 'have', this is assumed to manifest the incorporation of the abstract preposition. When faced with mixed systems like (15)-(16), we can now relabel 'have' and 'be', but we still have no prediction as to whether there will be some recurring, and more basic, syntactic patterns and, consequently, no reduction of the empirical variation observed (or still to be discovered). The number of bits of information remains the same. To understand just how many bits of information there can be, consider the auxiliation patterns in (18), described for four dialects of Abruzzi by Giammarco (1973):

(18) Abruzzi
a. L'Aquila
b. Vasto
c. Introdacqua
d. Notaresco

\begin{tabular}{|c|c|c|cccc|}
\multicolumn{1}{c}{$1 \mathrm{sg}$} & \multicolumn{2}{c}{$2 \mathrm{sg}$} & \multicolumn{1}{c}{$3 \mathrm{sg}$} & $1 \mathrm{pl}$ & $2 \mathrm{pl}$ & $3 \mathrm{pl}$ \\
\hline $\mathrm{E}$ & $\mathrm{E}$ & $\mathrm{H}$ & $\mathrm{E}$ & $\mathrm{E}$ & $\mathrm{H}$ \\
\hline $\mathrm{H}$ & $\mathrm{E}$ & $\mathrm{E} / \mathrm{H}$ & $\mathrm{H}$ & $\mathrm{H}$ & $\mathrm{H}$ \\
\hline $\mathrm{H}$ & $\mathrm{E}$ & $\mathrm{H}$ & $\mathrm{H}$ & $\mathrm{H}$ & $\mathrm{H}$ \\
\hline $\mathrm{E}$ & $\mathrm{H}$ & $\mathrm{H}$ & $\mathrm{H}$ & $\mathrm{H}$ & $\mathrm{H}$ \\
\hline
\end{tabular}


This is but a small sample of the combinations that have been reported for central-southern Italian dialects (cf. the literature cited above in Sections 3.1-3.2 and the empirical evidence surveyed in Sections 5-6). Among these, the pattern in (18a), with aux $\mathrm{H}$ occurring in the third person singular and plural, seems to be more frequent than others, a fact that Tuttle (1986) explained in terms of semantic/pragmatic constraints, with reference to Benveniste's (1946) theory of verb person. ${ }^{19}$ This has been formalized by assuming a difference in the strength of person features in AGRs:

When BE is selected AGRs must have strong features which are activated by a subject with the appropriate features, namely first or second person, passing through its Spec (Ledgeway 1998: 136).

Third person (Benveniste's "non-person") is assumed to lack strong features, which would explain selection of aux $\mathrm{H}$. Yet the fact remains that the pattern in (18a) is only one in an ocean of other possibilities. Those in (18b)-(18d) are just a limited sample, and we will see some more later on, e.g., in (32)-(45). Actually, 'have' and 'be' can combine rather freely across verb persons in different dialects. There are also varieties in which aux $\mathrm{E}$ is selected just in the third person singular while aux $\mathrm{H}$ occurs elsewhere. This is the case for (at least some elderly speakers of) the Campanian dialect of Pompei, as seen in the paradigm of the unaccusative predicate našš 'be born' (cf. Cennamo 2001: 444):

\begin{tabular}{|c|c|c|c|}
\hline Pompei & & & \\
\hline 1sg ağğə na:tə & $\mathrm{H}$ & $1 \mathrm{pl}$ & ammə na:tə \\
\hline a na:tə & $\mathrm{H}$ & $2 \mathrm{pl}$ & ato na:tə \\
\hline$\varepsilon$ na:tə & E & $3 \mathrm{pl}$ & annə na:tə \\
\hline
\end{tabular}

These and similar facts fly in the face of Kayne's approach, as argued by Cennamo (2001) and Bentley and Eythórsson (2001: 70-71). Apparently, the additional hypothesis connecting auxiliary selection to strong vs. weak features does not salvage this approach from its circularity.

An elementary calculation will help us to realize the combinatorial complexity of Italo-Romance options in auxiliary choice. The six verb persons are six independent variables, and each of these can have one of three distinct values, viz. 'have', 'be' or free variation of both ('have'/'be'). This adds up to $3^{6}=729$ conceivable auxiliation patterns, on the assumption that auxiliation in mixed systems is not sensitive to clause type (like in Acquafondata [15], and contrary to Standard Italian [9]). Combining this result with the theoretical possibility of a binary contrast of the Italian kind gives $729^{2}=531,441$. If we also admit the possibility of 3-aux systems, the result goes into the millions. 
It could be the case, in principle, that all of these empirical possibilities are documented, and very many of them are indeed. What is inconceivable, however, is for this empirical variability to be directly encoded into structural categories in a one-to-one correspondence. This is the implication of Kayne's approach: since "there is no auxiliary selection rule", formalization of the syntactic mechanism of auxiliary selection - however complex and, in itself, interesting - simply mirrors empirical variation in the lexical items $\mathrm{H} / \mathrm{E}$.

\subsection{Mixed auxiliation in the syntactic approach}

We shall take a different route. With regard to mixed systems as well, the basic questions to ask are the following: how many contrasting auxiliary choices are selected in different clause types; and how exactly do clause types group in selecting auxiliation patterns? Under this view, the mixed system found in Southern Lazio (Aquafondata, [15]) is not different from the Spanish type in (2). Both systems have departed from Proto-Romance — still mirrored in Italian - in that they have generalized one auxiliation pattern and have given up the original binary contrast so that auxiliation lost its original ability to signal active/inactive alignment. What has taken place in Spanish and in dialects like (15) is the same syntactic change, although implemented with different morpho-lexical means.

Of course, once we have described in these terms the syntax of auxiliation in the dialect of Acquafondata, we still have to specify where precisely (in which verb persons) the morphemes 'have' and 'be' occur. This is, however, a matter of morphology, not syntax (cf. Loporcaro 2001: 462), just like, say, the description of different personal endings within a paradigm. Bentley and Eythórsson (2001: 71) argue in favor of this view, concluding that "alternation according to person is part of a grammatical marking system on verbs".

If this is true (and the syntactic approach to auxiliation is on right track), then we can expect a limited number of recurring structural patterns to be recognizable under (and in spite of) the huge surface variation exemplified in (15)-(16) and (18). We will see in Section 5 that this expectation is borne out by the data. To see this, we first have to elaborate a bit on the set of relevant clause types we have discussed up to now.

\section{Romance perfective auxiliation: an exhaustive syntactic typology}

Three structural classes have been distinguished so far: transitive, unergative and unaccusative. Inserting reflexives into the picture now expands 
the set. To illustrate, Italian examples are provided (the horizontal line separates selection of aux E from selection of aux $\mathrm{H}$ ):

(20) a. unaccusative

Maria è partita

M. is left.fsg

'Mary has left.'

b. direct transitive reflexive Maria si è lavata

M. refl is washed.fsg

'Mary has washed herself.'

c. indirect unergative reflexive

Maria si è risposta

M. refl is answered.fsg

'Mary has answered to herself.'

d. indirect transitive reflexive

Maria si è lavata le

M. refl is washed.fsg the

mani

hands

'Mary has washed her hands.' E

e. transitive/unergative

Maria ha mangiato (la $\mathrm{H}$
M. has eaten (the
minestra)
soup)
'Mary has eaten (the soup).'

Insertion of reflexives transforms the binary contrast considered so far into a scale. As seen in (20b)-(20d), three different classes of reflexive clauses are to be distinguished, viz. direct transitive (already introduced in [11b]), indirect unergative and indirect transitive, whose structural representations are given in (21a)-(21b):

\begin{tabular}{ccccc} 
(21) a. & 1,3 & & $\mathrm{P}$ & \\
& 1,2 & & $\mathrm{P}$ & \\
& 1 & & $\mathrm{P}$ & \\
\cline { 2 - 4 } & 1 & $\mathrm{P}$ & Cho & \\
& Maria & si è & risposta & \\
'Mary & has & answered & to herself.' \\
b. & 1,3 & & $\mathrm{P}$ & 2 \\
1,2 & & $\mathrm{P}$ & Cho \\
& & $\mathrm{P}$ & Cho \\
\hline 1 & & $\mathrm{P}$ & Cho & Cho \\
& Maria & si è & lavata & le mani \\
'Mary & has & washed & her hands.'
\end{tabular}


The analyses in (21a)-(21b) were originally proposed by La Fauci (1988: 82-88), to which the reader is referred for the empirical justification of the $3 \rightarrow 2$ advancement that is assumed to take place before multiattachment is finally resolved, as foreseen in Rosen's (1982) theory of reflexives (cf. Section 1.2). A further structural subclass of reflexives is exemplified in (22):

(22) a. Gianni s'è beccato una multa
'Gianni has gotten a fine.'
\begin{tabular}{cccc} 
b. & 1 & $\mathrm{P}$ & 2 \\
1,2 & $\mathrm{P}$ & Cho \\
1 & & $\mathrm{P}$ & Cho \\
\hline 1 & $\mathrm{P}$ & Cho & Cho \\
Gianni & s'è & beccato & una multa \\
'Gianni & has & gotten & a fine.'
\end{tabular}

Like (21b), (22) involves a transitive predicate. While the two are traditionally equated by assuming that the final subject in (22) also is an indirect object, ${ }^{20}$ La Fauci (1984: 225-229) pointed out that the latter construction is better analyzed as a de-transitivized clause, in which multiattachment fulfils a purely syntactic function, as shown in the structural representation (22b). Appearance of clitic si on the predicate is simply the (Romance) way to signal detransitivization via demotion of the initial direct object, ${ }^{21}$ which is in turn the defining property of the class of constructions called 'antipassive' in the typological literature (cf. e.g., Givón 1994: 8-9; Dixon 1994: Section 6.1; cf. also Loporcaro 1998: 106-107 for Romance empirical evidence in favor of analysis [22b], as well as Postal 1977: 351; Davies 1984: 332; Davies and Sam-Colop 1990: 538; and Mejías-Bikandi 1990: 275 for analyses of antipassive in Eskimo, Choctaw, K'iche' and Basque, respectively, within the same framework adopted here). ${ }^{22}$

As far as auxiliation is concerned, however, antipassives turn out to behave just like indirect transitive reflexives. This is far from surprising, since the two classes share a basic property: as is apparent from (21b) and (22b), they are dyadic constructions, since their nuclear term grammatical relations (1 and 2) are distributed over two distinct arguments. In (20b)-(20c), on the other hand, one single nominal argument bears both a subject and object relation (cf. the representations in [11b] and [21a]): these constructions can consequently be termed monadic reflexives, on analogy with monadic intransitive predicates (cf. e.g., Sorace 2000: 862). In conclusion, for our present purposes we can combine dyadic reflexives into one single step of our scale, viz. (20d), just like we did for transitives and unergatives (20e). ${ }^{23}$ 
The order in which the three classes of reflexives are listed in (20b)(20d) is motivated on both theoretical and empirical grounds. From what we have been saying while commenting on (22), as well as from the structural representations provided in (9), (11), (21) and (ib), in Note 23, it is apparent that dyadic reflexives (21b), (22b) are structurally more similar to (plain) transitives, whereas monadic reflexives are structurally more similar to unaccusatives (cf. Note 8).

Empirically, the scale in (20) mirrors an implicational generalization. $\mathrm{E} / \mathrm{H}$ selection varies stepwise, across Romance, along this scale, which is projected onto the horizontal dimension in (23) (considering first only nonmixed systems).
a. Italian
b. Sardinian
c. ?
d. Vallader
e. Spanish

\begin{tabular}{|c|c|c|c|c|c|}
\hline \multicolumn{4}{|c|}{ inactive } & \multicolumn{2}{|c|}{ active } \\
\hline \multirow[t]{2}{*}{ unaccus. } & \multicolumn{3}{|c|}{ reflexive } & \multirow{2}{*}{\multicolumn{2}{|c|}{ transit. unergat. }} \\
\hline & $\begin{array}{l}\text { dir. } \\
\text { trans. }\end{array}$ & $\begin{array}{l}\text { ind. } \\
\text { uner. }\end{array}$ & $\begin{array}{l}\text { ind. } \\
\text { trans. }\end{array}$ & & \\
\hline \multicolumn{4}{|l|}{$E$} & & $\mathrm{H}$ \\
\hline \multicolumn{4}{|l|}{$E$} & & $\mathrm{H}$ \\
\hline \multicolumn{4}{|l|}{$E$} & & $\mathrm{H}$ \\
\hline \multirow[t]{2}{*}{$\mathrm{E}$} & & & & & $\mathrm{H}$ \\
\hline & & & & & $\mathrm{H}$ \\
\hline
\end{tabular}

Note first that this implicational scale closely parallels the one which emerged from Loporcaro's (1998) study of Romance PtP agreement. ${ }^{24}$ The convergence is hardly surprising, once the typological framework in Section 2 has been set. Since both PtP agreement and auxiliation are originally sensitive to active alignment, loss of this sensitivity proceeds through much the same steps, applying to first those reflexives that are closer to transitives, monadic reflexives next, and unaccusatives last. However, recognition of the typological coherence between the two diachronic processes (2-aux $>1$-aux and reduction of PtP agreement) is not tantamount to claiming that the latter simply depends on the former, as maintained in traditional descriptive grammars as well as in Romance linguistics (since Diez), and still currently claimed by recent formalized revivals of the traditional view (cf. above, Section 1.1 and Note 4). ${ }^{25}$

The labels in (23) are merely suggestive. The 'Italian' auxiliation type is the same found in French, in most dialects of Gallo-Romance and in many varieties of central and northern Italo-Romance. ${ }^{26}$ The "Spanish" 
type dominates in the Iberian Peninsula, but is also found in DacoRomance, in Sicilian and in several other dialects of southern Italy spoken in Calabria (e.g., Trebisaccese, cf. [4] above), Apulia (e.g., Tarantino, cf. Greco 1973-1974: 73), and Lucania, as shown in the following examples from the dialect of Irsina (Matera province):

(24) Irsina

unergative/transitive/unaccusative

1sg ye:jə affə manğe:tə/ kott a past/ vəno:tə tard I have eaten/ cooked the pasta/ come late

'I've eaten/cooked pasta/come late.'

2 sg to e: manğe:tə/kətt a past/vəno:tə tard

3 sg yidd a mmanğe:tə/kkott a past/vvəno:tə tard

$1 \mathrm{pl}$ no:i ammə manğe:tə/kstt a past/vəno:tə tard

$2 \mathrm{pl}$ vo:i á:vətə manğe:tə/kott a past/vəno:tə tard

$3 \mathrm{pl}$ lo:r annə manğe:tə/kətt a past/vəno:tə tard

direct transitive/retroherent/indirect unergative/indirect transitive reflexives

$1 \mathrm{sg}$ үe:jə $\mathrm{m}$ affə yars/ altse:tə/ kuttə/ I refl have burnt/ gotten-up/ cooked/

strend a čind

tightened the belt

'I've burnt myself/gotten up/cooked for myself/tightened my belt.'

2sg to t e: yars/ltse:tə/kuttə/strend a čind

3 sg yiddə s a yars/ltse:tə/kuttə/strend a čınd

$1 \mathrm{pl}$ no:i n ammə yars/altse:tə/kuttə/strend a čində

$2 \mathrm{pl}$ vo:i v á:vətə yars/altse:tə/kuttə/strend a čində

$3 \mathrm{pl}$ lo:rə s annə yars/altse:tə/kuttə/strend a čındə

Between the Italian (23a) and the Spanish (23d) types, three theoretically possible intermediate steps are found that would correspond to those actually observed for PtP agreement. However, among these hypothetical possibilities, only two have been empirically documented so far. ${ }^{27}$ Sardinian is an instance of type (23b) (translations of the Sardinian data in (25) - from the Logudorese dialect of Bonorva - are the same as for the Italian ones in (20); both auxiliation and $\pm \mathrm{PtP}$ agreement are highlighted by the horizontal line.)

(25) Sardinian
a. Maria es palti:ða
M. is left.fsg
b. Maria $\mathrm{z}$ es samuna:ða
M. refl is washed.fsg 

c. Maria $z \quad$ er risposta
M. refl is answered.fsg
$\mathrm{E} /+\mathrm{PtPagr}$
d. Maria z a ssamuna:ðu zal ma:nos H/-PtPagr
M. refl has washed.msg the hands
e. Maria a mmaniya:ðu (za minestra)
M. has eaten.msg (the soup)

Type (23d) is instanced by several varieties of Northern Italy and the Rhaeto-Romance area (cf. Loporcaro 1998: 90-101, 124-131), here exemplified with Vallader, spoken in the lower Engadine (cf. Ganzoni 1983): ${ }^{28}$

(26) Vallader
a. ellas sun idas
b. ella s' ha lavada H she refl has washed 'She has washed herself.'
c. Dora e Mengia s' han scrittas suvent D. and M. refl have written.fpl often
'D. and M. have written often to each other.' +PtP agr
d. ella s' ha lavà ils mans - PtP agr she refl has washed the hands
'She has washed her hands.'
e. el ha fingià muns (trais vachas)
he has already milked (three cows)

In Sardinian, indirect transitive reflexives pattern with plain transitives and unergatives in selecting aux $\mathrm{H}$ (and lacking PtP agreement), whereas in Vallader only unaccusatives select 'be', and 'have' is selected elsewhere (but PtP agreement is preserved with monadic reflexives [26b]-[26c], in spite of selection of aux $\mathrm{H}$ ).

The Sardinian type, which is found all over the island (cf. Jones 1988: 334, 1993: 130-134; La Fauci and Loporcaro 1993: 163-165), seems to be quite widespread among continental dialects of Italo-Romance. One area in which auxiliation seems to conform to the Sardinian type is that of Gargano (Foggia province, northern Apulia). For the dialect of Mattinata, Granatiero (1987: 81) reports hèi mangétə/dərmútə 'I've eaten/ slept' with aux $\mathrm{H}$ (in all persons), like in m'hèi sciacquétə la faccə 'I've rinsed my face' (indirect transitive reflexive) and as opposed to aux E in sò ššuta 'I've gone', mə nə sò scurdétə 'I've forgotten' (retroherent unaccusative; cf. Note 23). The same situation is illustrated in (27) for the 
nearby dialect of Lesina with examples for third person singular only, since auxiliary choice is not sensitive to verb person:

(27) Lesina
a. jess $\varepsilon$ mmort
she is died.fsg
b. jessə $\check{c} \varepsilon$ llava:tə
she refl is washed
'She has washed herself.'
c. jessə $\check{c} \varepsilon$ rrəspunnu:tə so:lə she refl is answered alone

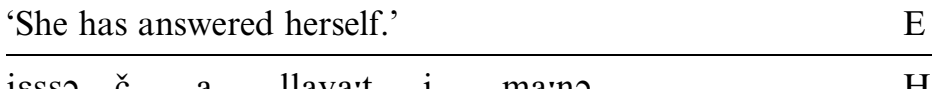
d. jessə $\check{c}$ a llava:t i ma:nə she refl has washed the hands 'She has washed her hands.'
$\begin{array}{lllllll}\text { e. iss a rrott } & \text { a bbuttiffə/ } & \text { a } & \text { kkammənát } & \text { assá } \\ \text { he has broken } & \text { the bottle/ } & \text { has walked } & \text { a-lot }\end{array}$

In central-northern Calabria, too, many dialects display the auxiliation pattern (23b), as exemplified in (28) with data from the dialect of San Giovanni in Fiore, spoken in the province of Cosenza, Northern Calabria (cf. Loporcaro 1998: 108-110; Solimando Carbone 2001: 65-69):

(28) San Giovanni in Fiore

a. maria $\varepsilon$ ttsasuita intsa

M. is entered.fsg inside

'Mary has gone inside.'

b. maria $\mathrm{z} \varepsilon$ llaßa:ta

M. refl is washed

'Mary has washed herself.'

c. maria $\mathrm{z} \quad \varepsilon$ ddispu:za zu:la

M. refl is answered alone

'Mary has answered to herself.'

d. maria $\mathrm{z}$ a dda:tu rui skaffi

M. refl has given two slaps

'Mary gave herself two slaps.'

e. maria a apíertu a porta

M. has opened the door

The table displaying auxiliation options in (23) qualifies as an implicational scale, since varieties do not seem to occur that show any one of the scattered distributions of the two auxiliaries exemplified below. 


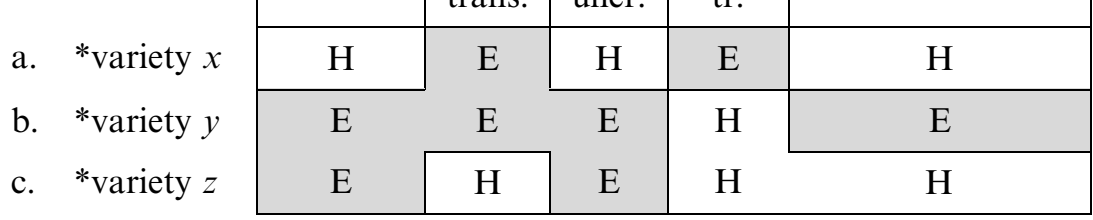

This empirical observation receives a straightforward explanation within the framework adopted here. Making use of the structural representations introduced in (9), (11) and (21) above, it is possible to describe all (and only) the options on the scale in (23) in a synthetic way, which yields a parametric account of Romance auxiliary selection (cf. La Fauci 1988: 91 for Italian; La Fauci and Loporcaro 1993: 164 for Sardinian; Loporcaro 1998: 129 for Vallader):

(30) Perfective auxiliary selection in Romance

a. aux $E$ iff the final 1 is: a 2 in the clause

Italian

b. aux $E$ iff the final 1 is: the first 2 in the clause Sardinian

c. aux $E$ iff the final 1 is: i. a 2 in the clause

ii. not multiattached Vallader

aux $\mathrm{H}$ elsewhere.

This parametric formulation accounts for the increasing restrictiveness of $\mathrm{E}$ auxiliation in (23a)-(23d) by either strengthening the initial condition (10) (the set of "first $2 \mathrm{~s}$ " is a subset of $2 \mathrm{~s}$ ) or adding a further condition (i.e., not multiattached). ${ }^{29}$ Conversely, there would be no structural possibility to state - in an equally synthetic way - generalizations accounting for the scattered distributions in (29a)-(29c), or for any other arbitrary combination. Thus, as in the case of PtP agreement, RG proves capable of constraining the empirically observed variation in Romance auxiliation in the desired way.

The alternative approach to auxiliary selection reviewed in Section 3.2, on the other hand, does not seem to provide any principled motivation for excluding any of the nonoccurring patterns exemplified in (29a)(29c). In fact, each of the auxiliary choices (in each individual cell in [29]) does occur in some variety. Thus, it must be describable in principle, and it can be indeed described by assuming $\mathrm{P}^{\circ}$ incorporation for 'have' vs. no incorporation for 'be', combined with the contrast of strong vs. 
weak features in AGRs. This approach, however, has little to say as to the constraints on the combinations of these auxiliary choices within one and the same system.

\section{Casting mixed systems into the Pan-Romance mould}

In this section, the grid in (23) will be put to the test by reverting to dialects with mixed auxiliation. The vast majority of mixed systems described so far for Italo-Romance dialects concentrates in central-southern Italy. In view of the structural contrast encoded by auxiliation, these dialects seem to fall into two subgroups which can be identified with either the Spanish (23e) or the Sardinian (23b) type (with a residue, that of 3aux systems, to be finally dealt with in Section 6).

\subsection{The Spanish type}

We have already ascribed the dialect of Acquafondata (15) to the former subgroup, in which a single auxiliation pattern (identical to that in [18a]) was shown to occur in unaccusatives as well as in transitives/unergatives. In this dialect, all classes of reflexives conform to the same auxiliation pattern:

(31) Acquafondata

direct transitive indirect transitive reflexive reflexive

1sg mə so llava:tə mə so llava:tə la ma:nə tsəttsə E refl am washed refl am washed the hand dirty

'I've washed 'I've washed my dirty hand.' myself.'

2sg to si llava:tə to si llava:tə la mainə tsottsə

3sg ts a lava:tə ts a lava:tə la ma:nə tsottsə $\mathrm{H}$

$1 \mathrm{pl}$ t $\int$ ə se:mə lava:tə mə sə llava:tə la ma:nə tsəttsə $\mathrm{E}$

$2 \mathrm{pl}$ və se:tə lava:tə to si llava:tə la ma:nə tsottsə

$3 \mathrm{pl}$ ts an:ə lava:tə ts a lava:tə la ma:nə tsottsə $\mathrm{H}$

This kind of system, with an invariable auxiliation pattern whatever the exact distribution of aux $\mathrm{E} / \mathrm{H}$ across persons, is widespread: many such cases are described for dialects of central and southern Italy in e.g., Giammarco (1973), Tuttle (1986) and Lorenzetti (1995: 223-267). A number of these dialects display the same distribution (aux $\mathrm{H}$ in third persons, aux E in first and second), but it need not be so, as already argued in 
Section 3.3 with data from the Abruzzi, which could easily be multiplied for other areas of central-southern Italy. In Apulia, the dialect of Bisceglie (Bari province) has one auxiliation pattern for all verb classes, with aux E in the 2sg and aux H elsewhere (cf. De Gregorio 1939: 50), as schematically shown in (32a). In nearby Giovinazzo (data in [33], from Manzini and Savoia 1998: 130-131), aux E occurs in the 1sg and 2sg for all classes of predicates and aux $\mathrm{H}$ is selected in the remaining persons (32b):

a. Bisceglie
b. Giovinazzo

\begin{tabular}{|c|c|ccccc|}
\multicolumn{1}{c}{1 sg } & \multicolumn{2}{c}{2 sg } & 3 sg & $1 \mathrm{pl}$ & $2 \mathrm{pl}$ & $3 \mathrm{pl}$ \\
\hline $\mathrm{H}$ & $\mathrm{E}$ & $\mathrm{H}$ & $\mathrm{H}$ & $\mathrm{H}$ & $\mathrm{H}$ \\
\hline $\mathrm{E}$ & $\mathrm{E}$ & $\mathrm{H}$ & $\mathrm{H}$ & $\mathrm{H}$ & $\mathrm{H}$ \\
\hline
\end{tabular}

(33) Giovinazzo

unergative/transitive/unaccusative

1sg so drəmméuntə/lave:tə la mákənə/ mə sə lave:tə E vənéuto

am slept/ washed the car/ come refl am washed

'I've slept/washed my car/come.' 'I've washed myself'

2sg si drəmméuntə/lave:tə la mákənə/ to si lave:tə E vənéuto

3sg a drəmméutə/lave:tə la mákənə/ s a lave:tə $\quad \mathrm{H}$ vənéutə

$1 \mathrm{pl}$ ammə drəmméútə/lave:tə la $\mathrm{n}$ ammə lave:tə $\mathrm{H}$ mákənə/vənéútə

2pl avi:tə drəmméutə/lave:tə la $\quad \mathrm{v}$ avi:tə lave:tə $\mathrm{H}$ mákənə/vənéútə

3pl annə drəmméútə/lave:tə la s annə lave:tə $\mathrm{H}$ mákənə/vənéútə

The Giovinazzese pattern was analyzed by Manzini and Savoia (1998: 130-131). Elaborating on Kayne (1993), the authors propose that mixed auxiliation systems are driven by a "person ergativity split" of the kind familiar from the typological literature, as observed for instance in Dyirbal. In this language, first and second person pronouns have accusative case marking, whereas third person pronouns and other nominals have ergative case marking (cf. Dixon 1994: 85-86). This would apply to the type exemplified for Acquafondata in $(15) /(31)$, where the contrast in the auxiliary is found in both the singular and plural, as well as to the dialect of Giovinazzo, where the contrast is limited to the singular. The explanation proposed for this asymmetry appeals to a well-known pragmatic circumstance: 
"The 1 ps corresponds to the speaker, the 2 ps to the listener; by contrast the $1 / 2 \mathrm{pp}$ include in their reference individuals other than the speaker and listener."

This would explain why, in Giovinazzo,

"only $1 / 2$ ps trigger the realization of all arguments within the inflectional $\mathrm{Cl}$ positions; this in turn gives rise to the choice of essere." (Manzini and Savoia 1998: 131).

This analysis, however, suffers from both empirical and theoretical shortcomings. On the empirical side, the same objections raised in Section 3.3 must be repeated: there are also dialects in which aux E occurs just in the third person singular and aux $\mathrm{H}$ occurs elsewhere (cf. [19] above). In Biscegliese aux E is selected only in the 2sg (cf. [32a]). In Gioia del Colle (also in the province of Bari), aux E is generalized in $1 \mathrm{sg}$ and $3 \mathrm{sg}$ (1sg I so ffatie:ta/ššuut/ffatto tando ko:s 'I've worked/gone/made so many things', 3sg jidd $\varepsilon$ ffatie:tə/ššuut/ ffatto tando ko:s) whereas transitives/unergatives preserve aux $\mathrm{H}$ in the 2sg (tu a fatie:ta/fatto tando kois 'you have worked/made so many things').

Briefly, the distribution of aux E/H across verb persons in mixed systems is not predictable, overall, on the basis of an alleged person ergativity split. It may be depicted as if it were only at the cost of picking out an arbitrary subset of the data (such as [18] and [32b]), while sweeping all the rest (such as [18b]-[18d] and [32a]) under the mat. At most, a split ergativity analysis may be adopted for Giovinazzese, while an entirely different one will have to be developed for the nearby dialects of Gioia, Bisceglie, Altamura (and a host of others). This solution, however, would contradict some results of current research on the typology of alignment. As Nichols' (1992: 163-183) quantitative study suggests, "dominant alignment shows the greatest stability in genetic groupings", as opposed to other syntactic properties such as basic word order. Since in our Apulian case we are dealing with closely related varieties, the null assumption is that they should not diverge on such an essential property as dominant alignment. On the contrary, accepting Manzini and Savoia's analysis would force us to claim that Giovinazzese has a person ergativity split, like, say, Dyirbal, whereas dialects spoken just a few miles away have none, like, say, English. Of course, changes in alignment do occur, as documented in Harris and Campbell (1995: Ch. 9). Such changes, however, are motivated by structural factors: e.g., passive-to-ergative reanalysis in Iranian languages, antipassive-to-accusative reanalysis in Kartvelian languages, or the like. For Giovinazzese - or for varieties of type (18a), for which 
the ergative split is also assumed - no evidence of this sort is provided. Thus, this analysis is implausible on theoretical grounds, given what is independently known on variation in alignment within genetic groupings.

\subsection{The Sardinian type}

Describing auxiliary selection in the dialects of Abruzzi, Giammarco (1973) claims that only mixed systems of the Sicilian type like those in (18a)-(18d) occur, with just one mixed pattern for all clause types. However, the data in (34)-(36) prove that Giammarco's conclusion was premature. They stem from the dialect of Pietransieri (Roccaraso), an Abruzzian variety spoken in the province of L'Aquila. My informants sharply distinguish the two auxiliation patterns exemplified in (34a)(34b) əvs. (34c)-(34d) for all six verb persons:

(34) Pietransieri

a. transitives

1 sg so fattə fešte $\quad$ E

am done party

'I've made merry.'

2 sg si fattə fešte $\quad$ E

3sg a fatto fešte $\quad \mathrm{H}$

$1 \mathrm{pl}$ e:mə fattə fešte $\quad \mathrm{H}$

2 pl e:tə fattə fešte $\quad \mathrm{H}$

$3 \mathrm{pl}$ e:nə fattə fešte $\quad \mathrm{H}$

b. unergatives

1sg so laura:tə tandə $\quad$ E

am worked much

'I've worked a lot.'

2sg si laura:tə tandə $\quad$ E

3sg a laura:to tando $\quad \mathrm{H}$

1pl e:mə laura:tə tandə $\quad \mathrm{H}$

2pl e:tə laura:tə tandə $\quad \mathrm{H}$

$3 \mathrm{pl}$ e:nə laurra:tə tandə $\quad \mathrm{H}$

c. unaccusatives

1 sg so juita

am gone

'I've gone.'

2 sg si juito

$\mathrm{E}$

3sg e juitə 
$1 \mathrm{pl}$ se:mə/e:mə ju:tə $\quad \mathrm{E} / \mathrm{H}$

$2 \mathrm{pl}$ se:tə/e:tə ju:tə $\quad \mathrm{E} / \mathrm{H}$

$3 \mathrm{pl}$ so jju:tə/e:nə ju:tə $\mathrm{E} / \mathrm{H}$

d. direct transitive reflexives

$1 \mathrm{sg}$ mə so lava:tə $\quad$ E refl am washed

'I've washed myself.'

2 sg to si lava:tə

E

3 sg s e llava:tə

$\mathrm{E}$

$1 \mathrm{pl} \quad(\mathrm{t})$ sə se:mə/(t)s e:mə lava:tə $\quad \mathrm{E} / \mathrm{H}$

$2 \mathrm{pl}$ və se:tə/v e:tə lava:tə $\quad \mathrm{E} / \mathrm{H}$

$3 \mathrm{pl}$ (t)sə so llava:tə/(t)s e:nə lava:tə $\quad \mathrm{E} / \mathrm{H}$

In transitives and unergatives, aux E occurs in the first and second person singular while aux $\mathrm{H}$ is found elsewhere (35b). In unaccusatives and direct transitive reflexives, aux $\mathrm{E}$ is selected in the singular and free variation of $\mathrm{E} / \mathrm{H}$ is found in the plural (35a).

(35) Pietransieri

a.

$\begin{array}{llllll}1 \mathrm{sg} & 2 \mathrm{sg} & 3 \mathrm{sg} & 1 \mathrm{pl} & 2 \mathrm{pl} & 3 \mathrm{pl}\end{array}$

b.

\begin{tabular}{|ccc|ccc|}
\hline E & E & E & E/H & E/H & E/H \\
\cline { 3 - 6 } E & E & $H$ & $H$ & $H$ & $H$ \\
\hline
\end{tabular}

Note that these data are at odds with Manzini and Savoia's (1998) claim, according to which the distribution of aux E/H in (35b) suggests a person ergativity split. In fact, it makes little sense to assume that such a split occurs, for one and the same language, in transitives and unergatives but not in unaccusatives and reflexives. This use of typological suggestions is ill founded: what is relevant for alignment is the contrast between clause types, and (34a)-(34b) vs. (34c)-(34d) is a contrast of the active/inactive type. For alignment, the distribution of the auxiliary morphemes $\mathrm{E} / \mathrm{H}$ across verb persons is irrelevant.

The data in (34) need to be supplemented with an example of dyadic reflexives. The complete set of relevant clause types is presented in (36), limited to the third person singular (all other persons behave the same way, with respect to the syntactic contrast at issue):

(36) Pietransieri

a. kelle donne e ju:te that woman is gone.fsg 'That woman has gone.' 
b. kelle donne s e warda:te (a ru speccə) that woman refl is looked-at (in the mirror) 'That woman has looked at herself (in the mirror).'

c. kelle donne $\mathrm{s}$ e skritte (pə ttandə tíəmbə) that woman refl is written (for much time)

'That woman has written to herself (for a long time).'

d. maríe s a messə ru kappíəllə

M. refl has put the hat

'Mary has put her hat on.'

e. marír a missə ru kappíəllə yga:p a ru fiKKə

M. has put the hat on-head to the son

'Mary has put the hat on her son's head.'

Crucially, dyadic reflexives pattern with transitives/unergatives. Thus, in spite of the fair amount of person-related variation, the auxiliation system structurally coincides with the Sardinian type (23b). We only need to substitute pattern (35a) for aux $\mathrm{E}$ and pattern (35b) for aux $\mathrm{H}$ :

(37) Pietrarolo

\begin{tabular}{|l|c|c|c|c|}
\hline \multicolumn{2}{|c|}{ inactive } & \multicolumn{1}{c|}{ active } \\
\hline \multirow{2}{*}{ unaccus. } & \multicolumn{2}{|c|}{ reflexive } & transit. unergat. \\
\cline { 2 - 3 } & dir. trans. & ind. uner. & indir. tr. & \\
\hline \multicolumn{2}{|c|}{$(35 \mathrm{a})$} & \multicolumn{2}{c|}{$(35 \mathrm{~b})$} \\
\hline
\end{tabular}

The same seems to be the case for many other varieties of centralsouthern Italy surveyed in Loporcaro (2001: 470-471).

Summing up, we started from the observation that mixed systems could hypothetically display not less than half a million different combinations of auxiliaries across verb persons. This combinatorial explosion can hardly be reduced to the neat binary contrast familiar from standard Italian or French, focusing on the lexical items 'be' and 'have', as implied by the lexical approach to auxiliary selection. However, as soon as the syntactic approach to auxiliation is adopted, it becomes possible to realize that there are in fact just two syntactically relevant major classes of mixed systems, that are perfectly homogeneous in nature to the non-mixed systems documented in "well-behaved", and better-known, Romance languages: those of the Spanish type and those of the Sardinian type. ${ }^{30}$ After this, one still has to describe in detail the empirically observed combinations of 'have' and 'be' across the paradigm. This is, however, an issue of morphology, not syntax. 


\section{Triple auxiliation}

From the foregoing discussion it should be clear that triple auxiliation systems can arise, in principle, when three different overall combinations of 'have'/'be' across the verb paradigm are assigned to three different subsets of clause types. The empirical problem is, then, to determine (a) whether 3-aux systems indeed exist; (b) if they do, how the three auxiliation options are distributed over the different clause types; and (c) whether the resulting systems obey the implicational generalizations established in (23).

\subsection{The Italian/Vallader type}

In northern Italy, triple auxiliation systems are frequently encountered among the dialects of Veneto, Trentino and Lombardia. Generally, in this area all types of reflexives (viz. [20b]-[20d]) pattern together and contrast with both unaccusatives and transitives/unergatives. While unaccusatives take 'be' and transitives/unergatives take 'have', just like in Italian, all reflexives display person-related alternation and/or free variation of aux $\mathrm{E} / \mathrm{H}$ in some or all persons of the paradigm.

Lepschy (1984) reports free variation of aux $\mathrm{E} / \mathrm{H}$ in reflexives for the dialect of Venezia. In varieties of southern Canton Ticino (cf. Lurà 1987: 169 on Mendrisiotto; and Pescia 1998: 21-24 on the dialect of Canobbio), reflexives have aux $\mathrm{E}$ in all six persons, like unaccusatives, but, unlike the latter, they also allow aux $\mathrm{H}$ in free variation with aux $\mathrm{E}$ in third persons only: e.g., 1sg ma sum/*m'u dissedaa 'I have woken up' vs. 3sg al s'è /s'à dissedaa 'he has woken up', 3pl i s'è(nn)/s'a(nn) dissedaa 'they have woken up'. The same happens in the dialect of Casale Corte Cerro (Verbania province), in the Lombard-Piedmontese transition area (Weber Wetzel 2002: 128) (examples are given in the 3sg only for the three classes of reflexives): 31

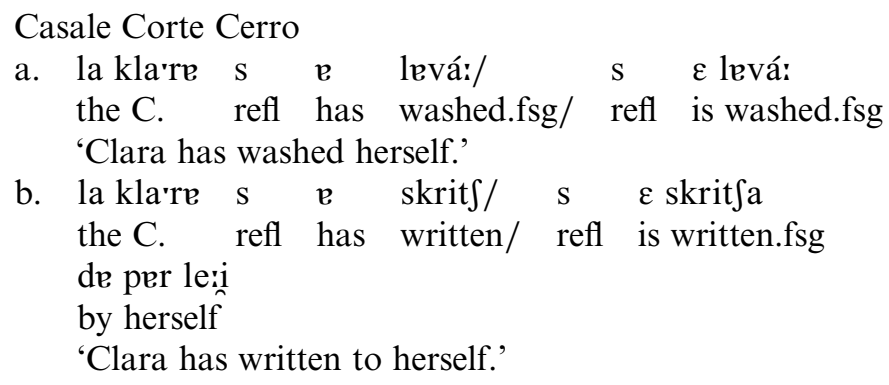

Casale Corte Cerro

a. la klaré $\mathrm{S} \quad \mathrm{e}$ levá:/ $\mathrm{s} \quad \varepsilon$ levá: the C. refl has washed.fsg/ refl is washed.fsg 'Clara has washed herself.'

b. la kla're $\mathrm{s} \quad \boldsymbol{e}$ skrits/ $\mathrm{s} \quad \boldsymbol{\varepsilon}$ skritja the C. refl has written/ refl is written.fsg de per le:i by herself

'Clara has written to herself.' 
c. la klarre s e levá/ s e levá:

the C. refl has washed/ refl is washed.fsg i mẽ

the hands

'Clara has washed her hands.'

Person-related alternation in reflexives is further illustrated in (39) with examples from Valsuganotto (in the variety spoken in Telve Valsugana, Trento province; cf. Loporcaro and Vigolo 1995: 98):

(39) Telve Valsugana

retroherent/indirect unergative/(in)direct transitive

1sg (mi) me son spaurá/zbará/lavá (le man) E

(I) refl am scared/shot/washed (the hands)

'(I) got scared/I shot myself/I washed myself/my hands.'

2sg (ti) te si spaurá/zbará/lava (le man)

$\mathrm{E}$

3sg el s a spaurá/zbará/lava (le man)

$\mathrm{H}$

$1 \mathrm{pl}$ (noaltri) ne son spaurái/zbarái/lavái (le man) E

$2 \mathrm{pl}$ (voaltri) ve sé spaurái/zbarái/lavái (le man) E

$3 \mathrm{pl}$ (lori) I s a spaurái/zbarái/lavái (le man)

$\mathrm{H}$

As highlighted through the capital letters in the right-hand column, reflexives select 'be' in first and second person vs. 'have' in the $3^{\text {rd }}$ person, in keeping with the most frequent pattern of alternation mentioned above in Section 3.3.

Actually, the auxiliation of reflexives in the different verb persons shows a great deal of variation, not only across dialects but also across groups of speakers of the same dialect. For Telve, for instance, the pattern in (39) is the preferred one, but for many informants 'have' is also at least marginally acceptable in the first and second person, as shown in (40a). Again, in other dialects of this area, several different combinations are found, some of which are listed in (40b)-(40c) (\% indicates that the relevant auxiliation option is acceptable for some speakers only):

(40) Auxiliation in reflexives (dialects of Valsugana):

\begin{tabular}{|c|c|c|c|c|c|c|}
\hline & $1 \mathrm{sg}$ & $2 \mathrm{sg}$ & $3 \mathrm{sg}$ & $1 \mathrm{pl}$ & $2 \mathrm{pl}$ & $3 \mathrm{pl}$ \\
\hline $\begin{array}{l}\text { a. Telve, } \\
\text { Torcegno, } \\
\text { Borgo }\end{array}$ & $\mathrm{E} /{ }^{\%} \mathrm{H}$ & $\mathrm{E} /{ }^{\%} \mathrm{H}$ & $\mathrm{H}$ & $\mathrm{E} /{ }^{\%} \mathrm{H}$ & $\mathrm{E} /{ }^{\%} \mathrm{H}$ & $\mathrm{H}$ \\
\hline $\begin{array}{l}\text { b. Serso, Susà, } \\
\text { Nogaré }\end{array}$ & $\mathrm{E} / \mathrm{H}$ & $\mathrm{E} / \mathrm{H}$ & $\mathrm{H}$ & $\mathrm{E} / \mathrm{H}$ & $\mathrm{E} / \mathrm{H}$ & $\mathrm{H}$ \\
\hline Pèrgine & $\mathrm{E} /{ }^{\%} \mathrm{H}$ & $\mathrm{E} /{ }^{\%} \mathrm{H}$ & $\mathrm{E} / \mathrm{H}$ & $\mathrm{E} /{ }^{\%} \mathrm{H}$ & $\mathrm{E} /{ }^{\%} \mathrm{H}$ & $\mathrm{E} / \mathrm{H}$ \\
\hline
\end{tabular}


There are clear differences with respect to the southern Italian dialects considered in Section 3 and Section 5. Firstly, person-related alternation is restricted to reflexives, with no variation at all in transitives/ unergatives and unaccusatives. Secondly, all reflexives pattern together, like in standard Italian and unlike in Sardinian or the mixed systems from central-southern Italy considered in (31)-(37). Thirdly, and most importantly, the number of distinct options in auxiliary selection is three, not two:

(41) Trentino

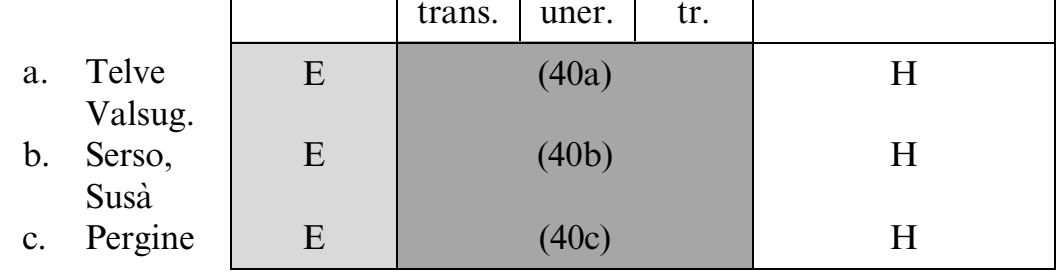

While the data from these northern Italian dialects have long been known, recognition of the fact that we are facing a 3-aux system has become possible only under the syntactic approach to auxiliation advocated here. These 3-aux systems can be characterized as resulting from a compromise between the Italian and the Vallader types - which also makes sense in a geolinguistic perspective, as many dialects of Veneto belong to the latter type (23d).

\subsection{The Italian/Sardinian type}

In central and southern Italy, too, a fair number of 3-aux systems is found. Not surprisingly, such systems are not easy to detect, as they are defined by contrasts observed in some persons only (even just in one), rather than in the whole paradigm (as in Section 6.1). For the same reason, these systems also happen to be unstable: in dialects of this type, it is not rare for different groups of speakers to have different grammatical intuitions on the acceptability of auxiliaries, at least in some persons for some syntactic constructions. 
One such case is that of the Apulian dialect of Altamura, considered above in (16) to exemplify free variation in all clause types with data limited to the first and second persons. In the third person, however, a contrast persists, as different clause types still display contrasting auxiliary choice. In the $3^{\text {rd }}$ person singular all speakers categorically reject (and never employ) aux $\mathrm{H}$ in unaccusatives or monadic reflexives:

(42) Altamura

$3^{\text {rd }}$ person singular

a. marí $\varepsilon /$ *a kkadúút

M. is/ has fallen

'Mary has fallen down.'

b. marí $\mathrm{s} \quad \varepsilon / *^{*}$ a llavéit

M. refl is/ refl has washed

'Mary has washed herself.'

c. marí $\mathrm{s} \quad \varepsilon /{ }^{*} \mathrm{~s}$ a rəspənnưu unt

M. refl is/ refl has answered

'Mary has answered to herself.'

d. marí $\mathrm{s} \quad \varepsilon / \mathrm{s}$ a llavé:tə la méin $\mathrm{E} / \mathrm{H}$

M. refl is/ refl has washed the hand

'Mary has washed her hand.'

e. marí $\varepsilon / a$ mmanğčit (la past)

M. is/has eaten (the pasta)

'Mary has eaten (pasta).'

In the $3^{\text {rd }}$ person plural, on the other hand, speakers' judgments vary as far as dyadic reflexives are concerned:

(43) Altamura

$3^{\text {rd }}$ person plural

a. marí e rro:sə so kkadưuut/ ppartưunt/ nne:t

$M$. and R. are fallen/ left/ born

a jaltamúurr// marí e rrossə awonnə kadúụt/

at Altamura// M. and R. have fallen/

partúunt/ne:t a jaltamúur

left/ born at Altamura

'Mary and Rose have fallen/left/were born in Altamura.'

b. marí e ffranğıskə sə so llavéit/vvəstưut/spusćit

$M$. and F. refl are washed/dressed/married

marí e ffranğıskə $\mathrm{s}$ awonnə

$M$. and $F$. refl have

lavéit/vəstưưt/spuséit

washed/dressed/married 
'Mary and Frank have washed/dressed themselves/got married.'

c. marí e ffranğiskə sə sə rrəspənnưunt/s awənnə $\mathrm{M}$. and F. refl are answered/ refl have rəsponnưunt answered

'Mary and Frank have answered to each other.' $\mathrm{E} / \mathrm{H}$

d. marí e ffranğıskə $\mathrm{s}$ awənnə lavé:t $/ \%$ sə

M. and F. refl have washed/ refl so llavé:t I méin are washed the hands

'Mary and Frank have washed their hands.'

e. marí e ffranğıskə awonnə manğčit/*so H $\mathrm{M}$. and $\mathrm{F}$. have eaten/ are mmanğéí (la past) eaten (the pasta) 'Mary and Frank have eaten (pasta).'

The contrasting behavior of the two subsets of speakers is further illustrated in (44), providing some more examples of indirect transitive reflexives (44a) and antipassives (44b)-(44d):
a. kiddə wannu:nə s awənnə de:tə/\% $/{ }^{\circ}$ ə so dde:tə those boys refl have given/refl are given mattséit
blows
'Those boys have beaten each other.'
b. kiddə wannu:nə s awənnə frəke:tə/ ${ }^{\%}$ sə so those boys refl have stolen/ refl are ffrəke:tə li sølt stolen the money
'Those boys have stolen the money.'
c. I sølt sə 1 awonnə frəke:tə/ $/{ }^{\%}$ sə the money refl DO.clit.3mpl have stolen/ refl li so ffroke:tə kidd DO.clit. $3 \mathrm{mpl}$ are stolen they '(The money) they have stolen it.'
d. $v$ kwappidd sə 1 awənnə pəff $\varepsilon: t ə /{ }^{\%}$ sə the hat refl DO.clit.3msg have taken/ refl lu so ppoffe:tə kidd DO.clit.3mpl are taken they '(The hat) they have taken it.'


For speakers rejecting aux E in dyadic reflexives (43d)-(44), the auxiliation contrast cuts across clause types at just the same point as in the 3sg: for these speakers, auxiliation is binary, consisting of the two options represented schematically in (45a)/(45c). For speakers judging both aux $\mathrm{H}$ and aux E as grammatical in (43d)-(44), on the other hand, dyadic reflexives contrast with unaccusatives (in the $3 \mathrm{sg}$ ) as well as with transitives/ unergatives (in the $3 \mathrm{pl}$ ). They constitute a third class (45b), whose syntactic behavior regarding auxiliation is intermediate:

(45) Altamura

\begin{tabular}{l|cc|c|ccc|}
\multicolumn{1}{c}{$1 \mathrm{sg}$} & \multicolumn{2}{c}{$2 \mathrm{sg}$} & \multicolumn{1}{c}{$3 \mathrm{sg}$} & $1 \mathrm{pl}$ & $2 \mathrm{pl}$ & $3 \mathrm{pl}$ \\
\cline { 2 - 7 } a. & $\mathrm{E} / \mathrm{H}$ & $\mathrm{E} / \mathrm{H}$ & $\mathrm{E}$ & $\mathrm{E} / \mathrm{H}$ & $\mathrm{E} / \mathrm{H}$ & $\mathrm{E} / \mathrm{H}$ \\
\cline { 2 - 7 } b. & $\mathrm{E} / \mathrm{H}$ & $\mathrm{E} / \mathrm{H}$ & $\mathrm{E} / \mathrm{H}$ & $\mathrm{E} / \mathrm{H}$ & $\mathrm{E} / \mathrm{H}$ & $\mathrm{E} / \mathrm{H}$ \\
\cline { 2 - 7 } c. & $\mathrm{E} / \mathrm{H}$ & $\mathrm{E} / \mathrm{H}$ & $\mathrm{E} / \mathrm{H}$ & $\mathrm{E} / \mathrm{H}$ & $\mathrm{E} / \mathrm{H}$ & $\mathrm{H}$ \\
\cline { 2 - 6 }
\end{tabular}

For both groups of Altamurano speakers, the auxiliation options can be displayed along the familiar implicational scale (23): ${ }^{32}$

\begin{tabular}{|c|c|c|c|c|c|}
\hline \multirow[b]{2}{*}{ Altamurano } & \multirow[t]{2}{*}{ unaccus. } & \multicolumn{3}{|c|}{ reflexive } & \multirow[t]{2}{*}{ transit. unergat. } \\
\hline & & $\begin{array}{l}\text { dir. } \\
\text { trans. }\end{array}$ & $\begin{array}{l}\text { ind. } \\
\text { uner. }\end{array}$ & $\begin{array}{c}\text { indir. } \\
\text { tr. }\end{array}$ & \\
\hline a. Altam. 1 & \multicolumn{3}{|c|}{ (45a) } & \multicolumn{2}{|r|}{$(45 c)$} \\
\hline b. Altam.2 & & (45a) & & $(45 b)$ & $(45 c)$ \\
\hline
\end{tabular}

As is apparent, the binary option (46a) corresponds structurally to the Sardinian type (23b). The 3-aux option (46b), on the other hand, differs from northern Italian 3-aux systems considered in (41): in the latter, free variation involves all reflexives and this determines a compromise between the Italian and the Vallader types, while in Altamurano the compromise is between the Italian and the Sardinian types. ${ }^{33}$

The same kind of auxiliation contrast (46b) is found in other 3-aux dialects spoken in central Italy, such as that of Colonna (Rome province). As in many other dialects of central Italy (cf. Note. 15), aux E has spread to all clause types in the 1st and 2nd person, as exemplified (for singular only) in (47): 
(47)

io so i:tu a la vinna/ so llavora:to/ so kko:tu u

I am gone to the vineyard/ am worked/ am picked the fjo:re

flower

'I have gone to the vineyard/have worked/have picked the flower.' tu si i:tu a la vinna/ si llavora:to/ si you are gone to the vineyard/are worked/ are kko:tu u fjo:re

picked the flower

'You have gone to the vineyard/have worked/have picked the flower.'

In the compound perfect, however, a distinction persists in $3 \mathrm{sg}$ and $3 \mathrm{pl}$, as exemplified for 3 sg only in (48):

(48) Colonna

a. essa $\varepsilon$ mmorta/*a morta

she is died.fsg/has died.fsg

'She has died.'

b. essa $\mathrm{n} \quad \mathrm{dz} \quad \varepsilon$ llava:ta/ $* \mathrm{n} \quad \mathrm{dz} \quad \mathrm{a}$ she neg refl is washed.fsg/ neg refl has lava:to/*-a

washed/washed.fsg

'She hasn't washed herself.'

c. kwella fémmina $\mathrm{s} \quad \varepsilon$ spara:ta/*s a that woman refl is shot.fsg/refl has spara:to/*-a shot/ shot.fsg

'That woman has shot herself.'

d. kwella fémmina $s \quad \varepsilon$ ppia:ta/ $s \quad$ a pia:to that women refl is taken.fsg/ refl is taken na kanğarra

a cold

'That women has gotten a cold.'

$\mathrm{E} / \mathrm{H}$

e. mójjita nun $\mathrm{t}$ a visto/* $\varepsilon$ vvisto $\mathrm{H}$

wife.poss.2sg neg DO.clit.2msg has seen/is seen 'Your wife hasn't seen you.'

While aux $\mathrm{H}$ persists as the only grammatical option in transitives/ unergatives (48e), in dyadic reflexives it alternates with aux E, so that the three auxiliation patterns emerge. ${ }^{34}$ 
(49) Colonna

\begin{tabular}{|c|c|c|c|c|c|}
\hline $1 \mathrm{sg}$ & $2 \mathrm{sg}$ & $3 \mathrm{sg}$ & $1 \mathrm{pl}$ & $2 \mathrm{pl}$ & $3 \mathrm{pl}$ \\
\hline $\mathrm{E}$ & E & $\mathrm{E}$ & E & E & $\mathrm{E}$ \\
\hline E & E & $\mathrm{E} / \mathrm{H}$ & E & E & $\mathrm{E} / \mathrm{H}$ \\
\hline E & E & $\mathrm{H}$ & E & E & $\mathrm{H}$ \\
\hline
\end{tabular}

The distribution of (49a)-(49c) across clause types is structurally the same as in the Altamurano case (46b), in spite of the quite different distribution of the morphemes 'have'/ 'be' in the paradigm.

A triple auxiliation system does not necessarily involve person-related alternation, though. In Macerata (central Marche; cf. Paciaroni 2002) aux $\mathrm{E}$ is selected (in all verb persons) in unaccusatives as well as monadic reflexives; aux $\mathrm{H}$ is selected in transitives/unergatives; and dyadic reflexives display variation of aux $\mathrm{E} / \mathrm{H}$, found in all verb persons (although with slight differences in acceptability across speakers). The Maceratese data are exemplified for $3 \mathrm{sg}$ only in (50):

(50) Macerata
a. issu $\varepsilon$ kkaška:tu
he is fallen
'She has fallen.'

b. essa $\mathrm{s} \quad \varepsilon$ rvišti:ta she refl is dressed.fsg

'She has dressed herself.'

c. essa $s \quad \varepsilon$ rrišpošta da per essa she refl is answered by herself

'She has answered to herself.'

d. essa $\mathrm{s} \varepsilon$ rlaa:ta/ $\mathrm{s}$ a rlaa:to le ma $\mathrm{E} / \mathrm{H}$ she refl is washed.fsg/ refl has washed the hands 'She has washed her hands.'
e. essa a faðiya:to H
'She has worked.'

The auxiliation system of Maceratese is thus structurally identical to the 3-aux option of Altamurano and Colonnese (46b).

\subsection{The Sardinian/Vallader type}

Southern Italian dialects offer further examples of 3-aux systems. Consider the dialects of central-northern Calabria (spoken in the region's 
northernmost province of Cosenza). We have already seen that, in this area, some varieties belong to the Sardinian type (like Sangiovannese; cf. [28] and [51a]) and others belong to the Spanish type (like Trebisaccese; cf. [5] and [51c]). Intermediate between these two options is the 3-aux system (51b) found in the dialect of Castrovillari (data in [52], from Pace 1993-1994: 129-130):

N. Calabria

a. S. Giovanni in $\mathrm{F}$.

b. Castrovillari

c. Trebisacce

\begin{tabular}{|c|c|c|c|c|}
\hline \multicolumn{2}{|c|}{ inactive } & active \\
\hline \multirow{2}{*}{ unaccus. } & \multicolumn{2}{|c|}{ reflexive } & transit. unergat. \\
\cline { 2 - 3 } & $\begin{array}{c}\text { dir. } \\
\text { trans. }\end{array}$ & $\begin{array}{c}\text { ind. } \\
\text { uner. }\end{array}$ & $\begin{array}{c}\text { indir. } \\
\text { tr. }\end{array}$ & \\
\hline \multicolumn{3}{|c|}{$\mathrm{E}$} & & $\mathrm{H}$ \\
\hline $\mathrm{E}$ & \multicolumn{2}{|c|}{$\mathrm{E} / \mathrm{H}$} & $\mathrm{H}$ \\
\hline \multicolumn{3}{|c}{$\mathrm{H}$} \\
\hline
\end{tabular}

(52) Castrovillari

a. maríja je mmorta

M. is died.fsg

'Maria has died.'

b. maríja $\mathrm{s} \quad \varepsilon / \mathrm{s}$ a vvistu:ta

M. refl is/refl has dressed.fsg

'Mary has dressed herself.'

$\mathrm{E} / \mathrm{H}$

c. ro:sa $\mathrm{s} \quad \varepsilon / \mathrm{s}$ a rrispursa surla

R. refl is/ refl has answered.fsg alone.fsg

'Rose has answered to herself.'

d. lorru s ann allurda:tu a kammisa

$\mathrm{H}$

they refl have dirtied the shirt

'They have dirtied their shirt(s).'

e. ro:sa a llava:tu na kammisa

R. has washed a shirt

In Castrovillarese, auxiliation is not sensitive to verb person. Like in Italian and Sardinian, aux E is selected in unaccusatives (52a) and aux $\mathrm{H}$ in transitives and unergatives (52e). Like in Sardinian and unlike in Italian, aux $\mathrm{H}$ is selected in dyadic reflexives too (52d). Finally, free variation of aux $\mathrm{H} / \mathrm{E}$ is found in monadic reflexives (52b)-(52c). As can be seen in (51b), this 3-aux system is a compromise between the Sardinian and the 
Vallader types. Clearly, in this case the rise of free variation in monadic, not in dyadic, reflexives cannot be ascribed to the influence of standard Italian, which has aux E throughout.

\subsection{Triple auxiliation systems: a summary}

Much like in the case of the other mixed systems (Section 5), our framework allowed us to recognize a highly restricted number of constant structural types for 3-aux systems, in spite of the great variety of surface distributions of the auxiliary morphemes (aux E vs. aux H). The 3-aux systems identified so far, surveyed in this section, in fact reduce to the three types illustrated in (41) (Veneziano, Trentino, some Lombard dialects), (46b) (Altamurano, Colonnese, Maceratese), and (51b) (Castrovillarese). This is an interesting and unexpected result, both in a structural and in a geographical perspective. Geographically, the three types fall within, rather than across, subdivisions traditionally recognized in Italian dialectology: the first one in northern Italy ('Gallo-Italic' and Veneto), the second in the adjacent 'Area Mediana' and 'Alto Meridione', the third in the 'Meridione Estremo'. Structurally, all of them can be easily formalised by making use of the representations introduced in (9), (11) and (21): (To also cover person-related alternation, auxiliation options are indicated generically with "aux-i", "aux-ii", "aux-iii"; for systems without person-related alternation, they correspond respectively to auxE, aux-E/H, aux-H.)

(53) Triple auxiliation in (some dialects of) Veneto, Trentino, and Lombardo

i. aux-i iff the final 1 is: a) a 2 in the clause

b) not multiattached

ii. aux-ii iff the final 1 is: a) a 2 in the clause

b) multiattached

iii. aux-iii elsewhere.

(54) Triple auxiliation in Altamurano, Colonnese, Maceratese

i. aux- $i$ if the final 1 is: the first 2 in the clause

ii. aux-ii if the final 1 is: a non-first 2 in the clause

iii. aux-iii elsewhere.

(55) Triple auxiliation in Castrovillarese

i. aux-i if the final 1 is: a) a 2 in the clause

b) not multiattached

ii. aux-ii if the final 1 is: a) the first 2 in the clause

b) multiattached

iii. aux-iii elsewhere. 
With this, the inventory of known auxiliation rules has been enriched: the generalizations in (30) and (53)-(55) add up to the most complete classification of Romance auxiliation mechanisms available to date. From this classification, an implicational pattern has emerged, as seen in the overview (23), complemented with (41), (46b) and (51b). This opens up interesting prospects for further empirical inquiry: we now have clear expectations about what we can possibly find, when we carry out fieldwork, since, as I hope to have shown, descriptive work on (especially Italo-)Romance dialects is far from exhausted and is likely to hold more interesting data in store. It is my contention, however, that the picture in (23), in its essence, will stand up to further empirical data. Having been established independently, it has in fact already proven successful, here, in classifying both non-triple mixed systems (Section 5) and 3-aux systems (Section 6).

\section{Conclusion}

Summing up, in this article I have proposed an inventory of Romance perfective auxiliation systems. The inventory is based on an implicational scale onto which all auxiliation options documented in Romance varieties can be mapped. This has been proven to work not only for the major standard languages but also for (a sample of) the dozens of lesser-known nonstandard varieties displaying free variation and/or person-related alternation in auxiliary choice. Among these, moreover, a fair number of 3-aux systems emerged.

This discovery, like all the descriptive results presented here, has become possible because we departed from the prevalent, but misleading, lexical approach to auxiliary selection and adopted the alternative syntactic approach to auxiliation, developed in work in Relational Grammar over the past two decades.

For research in formal syntax at the dawn of the third millennium, this change in perspective is quite radical. With the minimalist approach, generative syntax - the framework in which much of the work on Romance auxiliary choice is being carried out at present - has backed off from the original Chomskyan motto proclaiming the autonomy of syntax, which formed the main thrust of (early) generative grammar. What is nowadays considered as a desirable goal in this line of research is to develop analyses showing that whatever happens in syntax, both synchronically and diachronically, ultimately

... originates as an interface phenomenon, in the sense of Chomsky's Minimalist Program, perhaps just for reasons concerning the relation between language and 
the external world (pressures from the conceptual and articulatory-perceptual systems) (Longobardi 2001: 278). ${ }^{35}$

The investigation carried out in this article has shown that, for the empirical domain discussed, such a radical reductionist view does not pay off. The pervasive variation in auxiliary choice exemplified in Sections 3-6 directly mirrors syntactic change(s) that departed from the ProtoRomance 2-aux system. These changes, I have shown, cannot be reasonably reduced to lexical-semantic specification, let alone to (changes in) the "conceptual and articulatory-perceptual systems". Rather, recognizing that there is a significant level of analysis which is purely syntactic (i.e. autonomous from any other component) proves instrumental for a successful treatment of auxiliation and yields a spectacular reduction where previous research simply took stock of the variation in auxiliary morphemes, mistaken for syntactic variation due to the bias of the lexical approach.

The procedure followed here is in keeping with Perlmutter and Moore's (2002) "language internal explanation". A language internal explanation has been proposed, in this article, for each auxiliation system considered and has been integrated into a comparative picture which in turn reflects diachronic change. Although internal explanations are often accused of being circular, in our specific case the ordered picture of synchronic variation in (23) can be motivated independently, within a broader typological perspective. What we have analyzed are specific episodes of the general drift that brought all Romance varieties to shift back to accusative/ nominative alignment, abandoning the active/inactive alignment that shaped many morphosyntactic features of Proto-Romance.

Since Proto-Romance binary auxiliation belongs to the core of these active/inactive features (cf. Section 2), the change 2-aux $>1$-aux that took place in Spanish, Portuguese, Catalan, and Romanian is one manifestation of this alignment shift. The same is true for intermediate steps, such as the Sardinian type (23b), in which dyadic reflexives break the coherence of the set of inactive constructions. And the same goes for the rise of mixed systems, whatever the exact distribution of the morphemes aux $\mathrm{E} / \mathrm{H}$, since mixing automatically blurs the originally neat correlation between auxiliary and (active/inactive) alignment. The correspondence is entirely lost, of course, in mixed systems of the Spanish type. Again, this typological framing is possible under the syntactic approach to (mixed) auxiliation and contrasts with other kinds of typological parallels (discussed in Section 5.1-Section 5.2) drawn by syntacticians working in the generative paradigm.

Finally, the rise of 3-aux systems also makes sense in this perspective: in this case too, the original correspondence is blurred, so that 3-aux 
systems can be analyzed as (diachronically unstable) intermediate steps towards the loss of the original 2-aux rule. With this, all of the seemingly dispersed sets of data we have been discussing in this article find a plausible typological framing within the independently established diachronic dynamics of alignment in the history of Romance.

These results have been achieved by applying the conceptual tools of Relational Grammar. Unlike the analytical machinery, though, descriptive results are not theory-internal. While they testify to the merits of the model adopted, these results challenge work on Romance syntactic variation carried out within competing theoretical frameworks. Future treatments of variation in Romance auxiliary selection should be able to cope with at least the same range of data analyzed in this article and to propose an account that can rival for simplicity the one developed here.

Received 7 October 2003

University of Zurich

Revised version received

19 October 2004

\section{Notes}

* Parts of this research were presented in talks at the universities of Padua (February 2000), Konstanz (May 2000), Roma 3 (October 2003), Manchester (June 2000), in class lectures in Madison, WI (September 2000), and at the Summer School of the Association for Linguistic Typology (Cagliari, September 2003). I am indebted to the audiences for discussion. I also thank M.-D. Glessgen, Jean Hannah, and two anonymous referees for comments on a previous version, as well as all the speakers of the ItaloRomance dialects surveyed in Sections 3-6, who kindly shared their native intuitions with me. Correspondence address: Romanisches Seminar, Universität Zürich, Zürichbergstr. 8, Postfach 8028, Zürich, Switzerland. E-mail: loporcar@rom.unizh.ch.

1. The article is cast in the framework of Relational Grammar (henceforth RG) but takes a cross-theoretical perspective, considering analyses of Romance auxiliary selection couched in other theoretical frameworks and assessing their respective merits. In-depth familiarity with RG is not assumed: basic notions will be defined explicitly, if necessary with reference to an introductory handbook (Blake 1990).

2. In this article, I concentrate on the syntactic functions fulfilled by auxiliation at clause level and neglect related issues at the morphological and lexical-semantic levels. Thus, I shall abstract away from the fact that auxiliaries, in Romance and crosslinguistically, typically show morphological irregularity, as well as from the fact that perfective tenses built with auxiliaries display different aspectual and Aktionsart properties across Romance languages (cf. the overview in Squartini 1998).

3. Like all recent work on auxiliation in generative grammar, Lois' analysis assumes a structural contrast between two subclasses of intransitive predicates first put forward by Perlmutter (1978). 
4. This analysis actually boils down to the formalization of a traditional view, sanctioned in the first systematic study of Romance syntax by the founder of modern Romance linguistics:

Denn da habere in dieser Verbindung aus seiner concreten in eine ganz abstracte Bedeutung übergieng, [...], so mußte seine transitive Kraft nothwendig zurücktreten; es mußte mit dem folgenden Particip zu einem Begriffe verschmelzen, um das Object beherrschen zu können

[Since habere in this connection [scil. with the PtP] passed from its concrete meaning to a completely abstract one, its transitive force necessarily had to withdraw; it [scil. habere] had to blend with the following participle into one concept, in order to be able to govern its object] (Diez 1882 [1843]: 977).

5. Here and in what follows, I use a simplified IPA transcription, with $\check{s} \check{c} \breve{g}$ instead of $\int t \int$ $d_{3}$, CC instead of $\mathrm{C}$ :, and $\mathrm{V}$ instead of ' $\mathrm{V}$ (stress is marked only on oxytones and proparoxytones). Whenever unreferenced, data are drawn from my own field notes.

6. Under Davies and Rosen's theory, chômage also affects predicates, as is apparent in (9a)-(9b) where the initial (lexical) predicate is put en chomage by the auxiliary. Both representations in (9a)-(9b) are multistratal, consisting of more than one stratum (three and two, respectively). On the other hand, both contain two $P$ (redicate) sectors, defined as the set of strata in which a given predicate bears the P-relation (cf. Davies and Rosen 1988: 57).

7. Although proponents of RG were keen to emphasize the non-derivational nature of the model (cf. e.g., Postal 1977: 335-336), it is a fact that the vertical dimension in structural representations like (9a)-(9b) encodes syntactic processes (such as unaccusative advancement, passivization or the like).

8. More on the syntax of reflexives is given in Section 4. Like the UH in general, the specific solution to the problem of auxiliary selection in reflexives was also soon imported from RG into generative syntax. In the latter model, however, major problems arose due to the configurational definition of grammatical relations (cf. Alsina 1996: 81147; Loporcaro 1998: 213-215).

9. The inadequacy of Bessler's view stands out even more clearly if one takes reflexives into account. Spanish, Portuguese, Romanian, etc. all possess direct transitive reflexives. Assuming that selection of auxiliary 'have' directly indicates the absence of an initial 2, as Bessler does for unaccusatives, causes insurmountable problems if applied to these reflexive clauses since their argumental grid by definition does imply an initial 2 (as shown for Italian in [11b]).

10. Alternative approaches to Italian auxiliary selection continue to be proposed which regard it as directly determined by semantic properties of the intransitive predicate ([ \pm telicity]) and of its argument ([ \pm agentivity]): cf. e.g., Centineo (1986, 2001), Van Valin (1990). Some of these approaches regard unaccusativity as a scalar (semantically based) notion: cf. Sorace (2000); Cennamo (2001); Bentley and Eythórsson (2003); Keller and Sorace (2003) on German, etc. These treatments are less economical, as they single out just one manifestation of unaccusativity, providing more or less effective analyses, but have little to say about the host of other phenomena just listed, whereas the simple assumption of the binary structural contrast (9a)-(9b) automatically yields a straightforward account of all of them on a pan-Romance scale.

11. Many philological studies have documented the progressive retreat of auxiliary 'be' from perfective periphrastics in languages which are nowadays 1-aux varieties: cf. e.g., Benzing (1931); Cirot (1983 [1907]: 899-904) on Old Spanish; Huber (1933: 221) on Old Portuguese; La Fauci (1992: 202, 207) on Old Sicilian, etc. 
12. For the definition of active/inactive, I follow Harris (1997: 362), Harris and Campbell (1995: 241), elaborating on Sapir (1990 [1917]: 73), which is in turn one of the sources inspiring Perlmutter (1978: 186). In this view, an active/inactive system is defined as a system in which a subset of the arguments of monadic intransitives patterns with transitive objects while the complementary subset patterns with transitive subjects. Crucially, in this view active/inactive are purely syntactic labels, just like ergative/ absolutive and accusative/nominative: the labels refer to the alignment of grammatical relations and do not directly imply, for instance, that all verbs displaying "active" alignment have to be activities semantically and select an agentive subject. Different views on the topic are proposed e.g., in Mithun (1991: 542) and Dixon (1994: 77).

13. In work in linguistic typology it is generally assumed that "Basque is a prototypical representative of ergative structuring. It belongs to the rather rare type without any of the splits currently found." (Bossong 1984: 342; cf. also Brettschneider 1979: 371; Manandise 1987; Dixon 1994: 150; Palmer 1994: 54-54; 104-105). Yet the contrast (13a)(13b) is at odds with this traditional definition, and shows that Basque in its present form does not display ergative/absolutive but rather active/inactive alignment, although this terminological implication is generally not drawn in an explicit way even by authors describing the Basque intransitive split (Aldai 2000: 35 fn. 3; Levin 1989; Mejías-Bikandi 1990; Eguzkitza and Kaiser 1999: 199).

14. As for case marking on nonpronominal NPs, the situation was not as clear-cut. As is well known, Old French and Old Provençal preserved a binary contrast that grammars traditionally describe as nominative (cas sujet) vs. accusative (+oblique; cas régime). Many philological studies, however, have shown that both languages went through a stage in which the cas régime was extended as the unmarked case. As Pensado (1986) convincingly argues, this is quite atypical for an accusative system, where accusative is the marked case, and is reminiscent of "extended ergative" systems in Dixon's (1979) terminology, a label to which Dixon (1994: 63-67) substitutes the more perspicuous "marked nominative".

15. Auxiliary choice in this dialect is discussed in Cocchi (1995). The data in (15) stem from my own field notes (March 1999; I am especially indebted to Mr. Romolo Russo for his friendly help). In several dialects, including that of Acquafondata, auxiliary choice is also sensitive to tense, as aux E has fully generalized - to third persons as well - in perfective tenses other than the indicative compound perfect. For reasons of expository simplicity, I will neglect this further kind of alternation in what follows and exemplify mixed systems with compound perfect only.

16. Here and in what follows, in giving full paradigms I provide literal glosses and translation only for 1st person singular. From these, combined with the capitals on the righthand side, glosses and translations for the remaining persons can be inferred.

17. Aux $\mathrm{H}$ has two alternative forms in the $3 \mathrm{pl}$, viz. a:vo $<$ *habunt, the older one in this area of Central Italy, competing with annə, identical to Tuscan (and standard Italian) hanno.

18. Kayne's analysis is an instance of the reflexives-as-unaccusatives hypothesis mentioned in Note 8.

19. It was also claimed that "when «be» occurs only in one person, this is normally the 2sg" (Bentley and Eythórsson 2001: 67, quoting Hastings 1996 in support). While Hastings (1996: 34) reports this pattern (18c) for dialects of western Abruzzi, other varieties have aux E just in the 1sg (18d) or 3sg (19) and aux $\mathrm{H}$ elsewhere, so that the claim still awaits confirmation (perhaps through statistical counts).

20. This traditional conception of (22b) as involving a "dative of interest" (formally, an initially multiattached 3) is still widespread in theoretical studies of Romance syntax: e.g., Bentley and Eythórsson (2001: 66-67); Smith (2001). 
21. That Italian si can signal detransitivization is commonly admitted for initially transitive unspecified human subject constructions (also called "impersonal si passives"):

(i) le caldarroste si vendono in inverno

'roast chestnuts are sold in winter'

There is a huge literature on the topic, in formal syntax (cf. e.g., Rosen 1988 on Italian; Raposo and Uriagereka 1990 on Portuguese; Moore 1994: 391 on Spanish), linguistic typology (cf. Genušienè 1987: 110; Givón 1984: 235; Michaelis 1998: 90-93 etc.) and historical and comparative Romance linguistics (cf. e.g., Cennamo 1999; Wehr 1998).

22. With reference to Romance, the term "antipassive" has been used by Postal (1977) to label some constructions in French (cf. also Legendre 1994) which, however, do not involve a reflexive clitic and hence are not parallel with (22). Application of the term 'antipassive' to the latter has been criticized in the literature, most recently by Rosselló (2003: 354 fn. 11). The difference between these constructions and those termed "antipassive" in the typological literature is that the initial direct object in antipassives usually "goes into a peripheral function" and "can be omitted" (Dixon 1994: 146). While object optionality does not hold for our Romance constructions, they fulfill the remaining requirements established for antipassives by Dixon: the clause is finally intransitive (as evidenced by the fact that it cannot undergo passivization), and this change is signaled by an "explicit formal marking" (Dixon 1994: 146). Antipassive and reflexive marking coincide in many languages: cf. e.g., Dixon (1972: 89-95) on Dyirbal, Dixon (1977: 273-282) on Yidin, Dixon (1994: 147).

23. There is yet another class of constructions with reflexive si not included in (20), viz. that of unaccusatives with retroherent advancement (ia), as defined in Rosen (1982). The term "retroherent" indicates that the advancee keeps the 2 relation in the second stratum, as shown in (ib):

(i)

\begin{tabular}{ccc} 
a. & \multicolumn{3}{c}{ Maria si è svegliata } \\
'Maria has & woken up.' \\
b. & 2 & $\mathrm{P}$ \\
2,1 & $\mathrm{P}$ \\
1 & & $\mathrm{P}$ \\
\hline 1 & $\mathrm{P}$ & Cho \\
Maria & si è & svegliata
\end{tabular}

In modern standard Italian as well as in other modern Romance languages and dialects, this class of constructions patterns with direct transitive reflexives. However, in medieval Romance retroherent unaccusatives often display a distinctive behavior: they lose their reflexive clitics in compound tenses, where the perfective auxiliary 'be' already signals inactive status (cf. Parodi 1957: 85; Ageno 1964: 177; La Fauci 1992: 218-219). Formentin (2001: 113) shows that in Old Neapolitan texts from the 14th15 th c. retroherent unaccusatives differ in auxiliation (free variation of $\mathrm{E} / \mathrm{H}$ ) from other reflexives (aux $\mathrm{H}$ ) as well as from plain unaccusatives (aux E). This requires insertion of a new step onto the scale in (20), which I will ignore in the present context (where only modern Romance varieties are analyzed) for the sake of expository simplicity.

24. More precisely, the syntactic contexts ranged on the scale in $(20) /(23)$ are a subset of those that prove relevant in classifying variation in PtP agreement. The latter is sensitive to further structural contrasts such as the one between clitic vs. lexical transitive objects or between agreement with direct object clitics with lexical vs. causative/modal predicates. Indeed, direct object clitics have been argued to trigger a different auxiliary 
than lexical objects in some Italo-Romance dialects (cf. Lausberg 1939: 161-165; Manzini and Savoia 1998; Weber Wetzel 2002: 128). These phenomena, however, are not focused on in what follows. Passive auxiliation will not be dealt with either, a choice motivated in Note 30 below.

25. An instance of mismatch between PtP agreement and aux choice is illustrated in (26) below.

26. The classification in (23) abstracts away from contrasts such as Italian il libro è apparso (aux E) vs. French le livre a paru (aux H) 'the book has appeared'. These differences ultimately depend on the lexical specification of the verb lexemes concerned, not on the syntax of auxiliation (cf. La Fauci 2000: 86-89). The same goes for alternations found within one and the same language, such as Italian Gianni ha corso 'G. has run' vs. Gianni è corso a casa 'G. has run home'. This is a very well-known crosslinguistic phenomenon (cf. e.g., Levin and Rappaport Hovav 1992: 260 on English): a restricted set of predicates is specified in the lexicon as admitting both unergative and unaccusative constructions, the latter indeed boiling down to serialization on an initial locative predicate, as argued in Loporcaro (1998: $141 \mathrm{fn}$. 138). This variation, although somewhat more extended than implied by many, as thoroughly documented in Sorace's (2000) psycholinguistic study, is highly constrained and is not comparable with the systematic variation found in mixed systems (cf. Section 3).

27. Whether or not the other conceivable intermediate step (23c) really occurs is an empirical question, to be left for further research. The data available so far suggest that, for auxiliation, monadic reflexives (20b)-(20c) could be lumped together to form one single step on the scale. However, comparison with the PtP agreement facts suggest that the contrast direct transitive vs. indirect unergative might in principle play a role in some Romance varieties still to be discovered.

28. Type (23d) is documented in southern Italy as well, for example in Lecce and the surrounding dialects of Salento (Loporcaro 1998: 73). As is apparent from (26c), I use examples of reciprocal se-constructions together with reflexives, since for Romance seconstructions both semantic interpretations are available and no syntactic contrast is observed (a situation often met with crosslinguistically, although many other languages do have a formal contrast between the two classes: cf. e.g., Frajzyngier and Curl (1999a, 1999b) for a typological overview.

29. As to the 1-hood of the argument involved, the statement in (30) refers to final 1-hood following Perlmutter (1989: 82). In La Fauci and Loporcaro (1997: 31) a reformulation was proposed ("iff there is a nominal $a$ which is a 1 and has been a 2 in the clause"), intended to cover impersonal clauses too, whose final subject is an expletive. A formally neater statement, also covering impersonals, is Rosen's (1990: 415): "iff its Pinitial 1 bears the 2-relation in the same clause". I revert here to Perlmutter's original formulation for reasons of expository simplicity: in any case, the difference does not impinge on the present argument.

30. This radical simplification had a cost, though. Auxiliary selection rules which have been proposed for "well-behaved" Romance varieties in RG (cf. [30]) cover not only perfective but also passive auxiliation. In this study, passive is excluded for an elementary empirical reason: mixed auxiliation never extends to passive. Thus, if we want to account for mixed systems, in comparison with non-mixed ones, we have to separate out the passive. Integration of passive into this more complex picture will remain a task for further research.

31. Actually, in this dialect, while unaccusatives systematically take aux E, and unergatives and transitives (with a lexical direct object) take aux $\mathrm{H}$, unaccusatives with an indirect object clitic may switch to aux H (Weber Wetzel 2002: 128): 

(i) ku'ze t $\mathrm{e}$ kapité
what IO.2sg has happened
'What has happened to you?'

Consequently, in this dialect non-reflexive clitics pattern with reflexive clitics for auxiliary choice (cf. Note 24 above).

32. The Altamurano case shows how difficult it is to grasp the structural essence of such auxiliation systems. In Loporcaro (1988: 279-280), the difference in behavior between monadic and dyadic reflexives is overlooked and both categories are erroneously lumped together with unaccusatives (45a). Loporcaro (1998: 65, Fn. 8) recognizes that indirect transitive reflexives contrast with monadic reflexives, but still misses the fact that, for some speakers at least, they have an auxiliation pattern of their own (viz. [45b]), crucially defined by the fact that, in the third plural, they take both auxiliaries, unlike transitives/unergatives (45c).

33. In both cases the Italian type is involved, and in both cases there is evidence that the Italian-like contrast is an innovation: conservative dialects of Northern Veneto have only aux $\mathrm{H}$ in all reflexives (type [23d]), and elderly Altamurano speakers tend to have the binary option (46a). Hence the rise of these 3-aux systems may well have been favored by sociolinguistic pressure from the standard language (as suggested by one referee). Synchronically, however, the systems at issue do involve a three-way auxiliary choice. Note, further, that the external (contact-based) explanation is not available for the free variation documented for Altamurano in (16), which is extremely widespread in the central-southern Italian dialects and is much older than the diffusion of standard Italian into everyday spoken usage. Structural considerations also guarantee that this free variation is autochthonous. If in this area we find e.g., variation of aux $\mathrm{E} / \mathrm{H}$ in unaccusatives, the rise of this variation cannot be ascribed to contact with the standard because (a) the original (Proto-Romance) option was aux E, and (b) the standard preserves aux E.

34. As shown in Loporcaro (1999: 218-220), to which the reader is referred for more data and information on this dialect, aux $\mathrm{H}$ in dyadic reflexives seems to be the preferred option for elderly speakers, who, however, also accept aux E as grammatical. Thus, it may well be that this dialect, like the nearby variety of Zagarolo also studied in Loporcaro (1999), changed quite recently from a binary contrast of the Sardinian type (23d) to a 3-aux system as depicted in (49), possibly under the pressure exerted by the standard language.

35. See Bowern (2005) for a critique of Longobardi's views on syntactic change.

\section{References}

Ageno, Franca B[rambilla] (1964). Il verbo nell'italiano antico. Milan and Naples: Ricciardi. Alba Salas, Josep (2002). Lexically selected expletives: evidence from Basque and Romance. Unpublished manuscript, College of the Holy Cross, Worcester, MA.

Aldai, Gontzal (2000). Split ergativity in Basque: the pre-Basque antipassive-imperfective hypothesis. Folia Linguistica Historica 21, 31-97.

Alsina, Alex (1996). The Role of Argument Structure in Grammar: Evidence from Romance. Stanford, CA: CSLI.

Bentley, Delia and Eythórsson, Thórhallur (2001). Alternation according to person in ItaloRomance. In Historical Linguistics 1999: Selected Papers from the 14th International Conference on Historical Linguistics, Vancouver, 9-13 August 1999, Laurel J. Brinton (ed.), 63-74. Amsterdam and Philadelphia: Benjamins. 
- (2003). Auxiliary selection and the semantics of unaccusativity. Lingua 114, 447-471.

Benveniste, Emile (1946). Structure des relations de personne dans le verbe. Bulletin de la Société de Linguistique de Paris 43, 1-12.

- (1960). «Etre» et «avoir» dans leurs fonctions linguistiques. Bulletin de la Société de Linguistique de Paris 55, 113-134.

Benzing, Joseph (1931). Zur Geschichte von 'ser' als Hilfszeitwort bei den intransitiven Verben im Spanischen. Zeitschrift für romanische Philologie 51, 385-460.

Berchem, Theodor (1973). Studien zum Funktionswandel bei Auxiliarien und SemiAuxiliarien in den romanischen Sprachen. Morphologisch-syntaktische Untersuchungen über ,,gehen, haben, sein“. Beiheft 139 zur Zeitschrift für romanische Philologie. Tübingen: Niemeyer.

Bessler, Paul (1995). L'accord du participe passé dans les langues romanes: une approche morphosyntaxique. Canadian Journal of Linguistics/Revue Canadienne de Linguistique 40, 269-290.

Blake, Barry J. (1990). Relational Grammar. London: Routledge.

Bossong, Georg (1984). Ergativity in Basque. Linguistics 22, 341-392.

Bowern, Claire (2005). Syntactic change and syntactic borrowing in generative grammar. Unpublished manuscript, Rice University.

Brettschneider, Gunter (1979). Typological characteristics of Basque. In Ergativity: Towards a Theory of Grammatical Relations, Frans Plank (ed.), 371-384. London and New York: Academic Press.

Cennamo, Michela (1999). Late Latin pleonastic reflexives and the unaccusative hypothesis. Transactions of the Philological Society 97, 103-150.

-(2001). L'Inaccusatività in alcune varietà campane: teorie e dati a confronto. In Dati empirici e teorie linguistiche: Atti del XXXIII Congresso della Società di Linguistica Italiana, Napoli, 28-30 ottobre 1999, Rosanna Sornicola, Eleonora Stenta Krosbakken, and Carolina Stromboli (eds.), 427-453. Rome: Bulzoni.

Centineo, Giulia (1986). A lexical theory of auxiliary selection in Italian. Davis Working Papers in Linguistics 1, 1-35.

- (2001). Intransitive/pronominal alternations in Italian and Romance. Paper presented at the workshop Predicative Morphosyntax: Parameters of Variation in Romance, Palermo, November, 22-24, 2001.

Cirot, G. (1983 [1907]). Quelques remarques sur les archaïsmes de Mariana et la langue des prosateurs de son temps (conjugaison). In Festschrift Camille Chabaneau zur Vollendung seines 75. Lebensjahres 4. März 1906, dargebracht von seinen Schülern, Freunden und Verehrern, 883-904. Geneva [Erlangen]: Slatkine [Fr Junge].

Cocchi, Grazia (1995). La selezione dell'ausiliare. Padova: Unipress.

Davies, William (1984). Antipassive: Choctaw evidence for a universal characterization. In Studies in Relational Grammar 2, David M. Perlmutter and Carol Rosen (eds.), 331-376. Chicago and London: Chicago University Press.

- and Rosen, Carol (1988). Unions as multi-predicate clauses. Language 64, 52-88.

- and Sam-Colop, Luis Enrique (1990). K'iche' and the structure of antipassive. Language $66,522-549$.

De Gregorio, Iolanda (1939). Contributo alla conoscenza del dialetto di Bisceglie (Bari). L'Italia dialettale $15,31-52$.

Diez, Friedrich Christian (1882 [1843]). Grammatik der romanischen Sprachen: Dritter Theil, 5th ed. Bonn: Weber.

Dixon, Robert M. W. (1972). The Dyirbal Language of North Queensland. Cambridge: Cambridge University Press.

—(1977). A Grammar of Yidin. Cambridge: Cambridge University Press. 
-(1979). Ergativity. Language 55, 59-138.

-(1994). Ergativity. Cambridge: Cambridge University Press.

Eguzkitza, Andolin and Kaiser, Georg A. (1999). Postverbal subjects in Romance and German: Some notes on the Unaccusative Hypothesis. Lingua 109, 195-219.

Formentin, Vittorio (2001). L'ausiliazione perfettiva in antico napoletano. Archivio Glottologico Italiano 86, 79-117.

Frajzyngier, Zygmunt and Curl, Traci S. (eds.) (1999a). Reflexives: Forms and Functions. Amsterdam and Philadelphia: Benjamins.

—(eds.) (1999b). Reciprocals: Forms and Functions. Amsterdam and Philadelphia: Benjamins.

Ganzoni, Gian Paul (1983). Grammatica ladina. Grammatica sistematica dal rumantsch d'Engiadina Bassa per scolars e creschüts da lingua rumantscha e francesa. Samedan: Lia Rumantscha.

Genušienè, Emma (1987). The Typology of Reflexives. Berlin and New York: Mouton de Gruyter.

Giammarco, Ernesto (1973). Selezione del verbo ausiliare nei paradigmi dei tempi composti. Abruzzo 11, 152-178.

Givón, Talmy (1984). Syntax. A Functional-Typological Approach, vol. 1. Amsterdam and Philadelphia: John Benjamins.

- (1994). The pragmatics of de-transitive voice: functional and typological aspects of inversion. In Voice and Inversion, Talmy Givón (ed.), 3-44. Amsterdam and Philadelphia: John Benjamins.

Granatiero, Francesco (1987). Grammatica del dialetto di Mattinata. Comune di Mattinata.

Greco, Rosa Anna (1973-1974). Ricerca sul verbo nel dialetto tarentino. Studi linguistici salentini 6, 69-77.

Harris, Alice (1997). Review article of Dixon (1994). Language 73, 359-374.

- and Campbell, Lyle (1995). Historical Syntax in Cross-Linguistic Perspective. Cambridge: Cambridge University Press.

— and Ramat, Paolo (eds.) (1987). Historical Development of Auxiliaries. Berlin and New York: Mouton de Gruyter.

Hastings, Robert (1996). The dialects of Abruzzo and Molise. Quaderni di Ricerca del Centro di Dialettologia e Linguistica Italiana di Manchester 1, 21-38.

Heine, Bernd (1993). Auxiliaries. Cognitive Forces and Grammaticalization. New York and Oxford: Oxford University Press.

Hubbard, Philip Laurence (1985). The Syntax of the Albanian Verb Complex. New York: Garland.

Huber, Joseph (1933). Altportugiesisches Elementarbuch. Heidelberg: Winter.

Jones, Michael (1988). Sardinian. In The Romance Languages, Martin Harris and Nigel Vincent (eds.), 314-350. London: Croom Helm.

- (1993). Sardinian Syntax. London: Routledge.

Kayne, Richard S. (1993). Toward a modular theory of auxiliary selection. Studia Linguistica 47, 3-31.

Keller, Frank and Sorace, Antonella (2003). Gradient auxiliary selection and impersonal passivization in German: an experimental investigation. Journal of Linguistics 39, 57108.

Kempchinsky, Paula (1996). Perfective auxiliaries, possessives and existentials in Romance. In Grammatical Theory and Romance Languages, Karen Zagona (ed.), 135-144. LSRL 25. Amsterdam: John Benjamins.

Kuteva, Tanja (2001). Auxiliation. An Enquiry into the Nature of Grammaticalization. Oxford: Oxford University Press. 
La Fauci, Nunzio (1984). Sulla natura assolutiva del controllore dell'accordo del participio passato in italiano. La Memoria. Annali della Fac. di Lettere e Filosofia dell'Università di Palermo 3, 187-253.

-(1988). Oggetti e soggetti nella formazione della morfosintassi romanza. Pisa: Giardini. [Trans. 1994. Objects and Subjects in the Formation of Romance Morphosyntax. Bloomington, Indiana: IULC.]

- (1992). Capitoli di morfosintassi siciliana antica: tassonomia dei costrutti medi e ausiliari perfettivi. In Studi linguistici e filologici offerti a Girolamo Caracausi, 185-220. Palermo: Centro di studi filologici e linguistici siciliani.

- (2000). Forme romanze della funzione predicativa. Pisa: ETS.

- and Loporcaro, Michele (1989). Passifs, avancements de l'objet indirect et formes verbales périphrastiques dans le dialecte d'Altamura (Pouilles). Rivista di Linguistica 1, 161-196.

- (1993). Grammatical relations and syntactic levels in Bonorvese morphosyntax. In Syntactic Theory and the Dialects of Italy, Adriana Belletti (ed.), 155-203. Turin: Rosenberg and Sellier.

- (1997). Outline of a theory of existentials on evidence from Romance. Studi italiani di linguistica teorica e applicata 26, 5-55.

Lausberg, Heinrich (1939). Die Mundarten Südlukaniens. Beiheft 90 zur Zeitschrift für romanische Philologie. Halle: Niemeyer.

Ledgeway, Adam (1998). Avé(re) and esse(re) alternation in Neapolitan. In Studies on the Syntax of Central Romance Languages, Olga Fullana and Francesc Roca (eds.), 123-147. Girona: University of Girona.

Legendre, Géraldine (1994). Antipassive with French psych-verbs. In The Proceedings of the Twelfth West Coast Conference on Formal Linguistics, Erin Duncan, Donka Farkas, and Philip Spaelti (eds.), 373-388. Stanford, CA: CSLI.

Lepschy, Giulio (1984). Costruzioni impersonali con se in veneziano. In Guida ai dialetti veneti VI, Manlio Cortelazzo (ed.), 69-79. Padua: CLEUP.

Levin, Beth (1989). The Basque verbal inventory and configurationality. In Configurationality. The Typology of Asymmetries, László Marácz and Pieter Muysken (eds.), 39-62. Dordrecht: Foris.

- and Rappaport Hovav, Malka (1992). The lexical semantics of verbs of motion: the perspective from unaccusativity. In Thematic Structure. Its Role in Grammar, Iggy M. Roca (ed.), 247-269. Berlin: Foris.

Lois, Ximena (1990). Auxiliary selection and past participle agreement in Romance. Probus $2,233-255$.

Longobardi, Giuseppe (2001). Formal syntax, diachronic minimalism, and etymology: the history of French 'chez'. Linguistic Inquiry 32, 275-302.

Loporcaro, Michele (1988). Grammatica storica del dialetto di Altamura. Pisa: Giardini.

- (1998). Sintassi comparata dell'accordo participiale romanzo. Turin: Rosenberg \& Sellier.

- (1999). L'ausiliazione perfettiva nelle parlate di Zagarolo e di Colonna e lo studio della sintassi dei dialetti mediani. Contributi di Filologia dell'Italia Mediana 13, 203-226.

-(2001). La selezione dell'ausiliare nei dialetti italiani: dati e teorie. In Dati empirici e teorie linguistiche: Atti del XXXIII Congresso della Società di Linguistica Italiana, Napoli, 28-30 ottobre 1999, Rosanna Sornicola, Eleonora Stenta Krosbakken, and Carolina Stromboli (eds.), 455-476. Rome: Bulzoni.

- and Vigolo, M. Teresa (1995). Ricerche sintattiche sul confine dialettale veneto-trentino in Valsugana: l'accordo del participio passato. In Italia settentrionale: crocevia di idiomi romanzi, Emanuele Banfi; Giovanni Bonfadini, Patrizia Cordin, and Maria Iliescu (eds.), 87-101. Tübingen: Niemeyer. 
Lorenzetti, Luca (1992). Note sull'uso degli ausiliari nei dialetti dei Castelli Romani. Contributi di Filologia dell'Italia Mediana 6, 273-289.

-(1995). Aspetti morfologici e sintattici dei dialetti dei Castelli romani. Unpublished doctoral dissertation, University of Rome.

Lurà, Franco (1987). Il dialetto del Mendrisiotto. Descrizione sincronica e confronto coll'italiano. Mendrisio and Chiasso: Unione di Banche Svizzere.

Manandise, Esméralda (1987). AUX in Basque. In Historical Development of Auxiliaries, Martin Harris and Paolo Ramat (eds.), 317-344. Berlin and New York: Mouton de Gruyter.

Manzini, M. Rita and Savoia, Leonardo M. (1998). Clitics and auxiliary choice in Italian dialects: their relevance for the person ergativity split. Recherches linguistiques de Vincennes 27, 115-138.

Mejías-Bikandi, Errapel (1990). Clause union and case marking in Basque. In Grammatical Relations. A Cross-Theoretical Perspective, Katarzyna Dziwirek, Patrick Farrell, and Errapel Mejías-Bikandi (eds.), 263-277. Stanford, CA: CSLI.

Michaelis, Susanne (1998). Antikausativ als Brücke zum Passiv: fieri, venire und se im Vulgärlateinischen. In Neuere Beschreibungsmethoden der Syntax romanischer Sprachen, Wolfgang Dahmen, Günter Holtus, Johannes Kramer, Michael Metzeltin, Wolfgang Schweickard, and Otto Winckelmann (eds.), 69-98. Romanistisches Kolloquium XI. Tübingen: Narr.

Mithun, Marianne (1991). Active/agentive case marking and its motivations. Language 67, $510-546$.

Moore, John (1994). Reflexives, reflexive passives, and generalized chains. In The Proceedings of the Twelfth West Coast Conference on Formal Linguistics, Erin Duncan, Donka Farkas, and Philip Spaelti (eds.), 390-403. Stanford, CA: CSLI.

Nichols, Johanna (1992). Linguistic Diversity in Space and Time. Chicago: University of Chicago Press.

Pace, Anna (1993-1994). Ricerche di morfosintassi sui dialetti di Trebisacce e Castrovillari. Unpublished Laurea thesis, University of Calabria.

Paciaroni, Tania (2002). L'ausiliazione perfettiva in maceratese. Unpublished manuscript, University of Macerata.

Palmer, Frank R. (1994). Grammatical Roles and Relations. Cambridge: Cambridge University Press.

Parodi, Ernesto Giacomo (1957). Lingua e letteratura, Gianfranco Folena (ed.). Venice: Pozza.

Pensado, Carmen (1986). Inversion de marquage et perte du système casuel en ancien français. Zeitschrift für romanische Philologie 102, 271-296.

Perlmutter, David M. (1978). Impersonal passives and the Unaccusative Hypothesis. In Proceedings of the 4th Annual Meeting of the Berkeley Linguistic Society, Jeri J. Jaeger, Anthony C. Woodbury, Farrell Ackermann, Christine Chiarello, Orin D. Gensler, John Kingston, Eve E. Sweetser, Henry Thompson, and Kenneth W. Whistler (eds.), 157-189.

- (1989). Multiattachment and the Unaccusative Hypothesis: the perfect auxiliary in Italian. Probus 1, 63-119.

- and Moore, John (2002). Language-internal explanation: the distribution of Russian impersonals. Language 78, 619-650.

Pescia, Lorenza (1998). Note di sintassi sul dialetto di Canobbio. Unpublished Lizenziatsarbeit, University of Zurich.

Postal, Paul (1977). Antipassive in French. Linguistice Investigationes 1, 333-374.

Ramat, Paolo (1987). Introduction. In Historical Development of Auxiliaries, Martin Harris and Paolo Ramat (eds.), 3-19. Berlin and New York: Mouton de Gruyter. 
Raposo, Eduardo and Uriagereka, Juan (1990). Object agreement in the impersonal-se passive construction in European Portuguese. In Grammatical Relations. A Cross-Theoretical Perspective, Katarzyna Dziwirek, Patrick Farrell, and Errapel Mejías-Bikandi (eds.), 387399. Stanford, CA: CSLI.

Rohlfs, Gerhard (1966-1969). Grammatica storica della lingua italiana e dei suoi dialetti, 3 vols. Turin: Einaudi.

Rosen, Carol (1982). The Unaccusative Hypothesis and the 'inherent clitic' phenomenon in Italian. Chicago Linguistic Society 18, 530-541.

- (1988). The Relational Structure of Reflexive Clauses. New York: Garland.

- (1990). Italian evidence for multi-predicate clauses. In Grammatical Relations. A CrossTheoretical Perspective, Katarzyna Dziwirek; Patrick Farrell; and Errapel Mejías-Bikandi (eds.), 415-444. Stanford, CA: CSLI.

- (1997). Auxiliation and serialization: on discerning the difference. In Complex Predicates, Alex Alsina, Joan Bresnan, and Peter Sells (eds.), 175-202. Stanford, CA: CSLI.

Rosselló, Joana (2003). Review of Loporcaro (1998). Estudis romànics 25, 348-363.

Sapir, Edward (1990 [1917]). Review of C. C. Uhlenbeck: Het passieve karakter van het verbum transitivum of van het verbum actionis in talen van Noord-Amerika. Verslagen en Mededeelingen der Koninklijke Akad. van Wetenschappen, Afd. Letterkunde, Vijfde Reeks, Tweede Deel, 187-216 (1916). International Journal of American Linguistics 1, 82-86. In The Collected Works of Edward Sapir, vol. 5, American Indian Languages, 1, William Bright (ed.), 69-74. Berlin and New York: Mouton de Gruyter.

Smith, John Charles (2001). L'analyse des pronoms éthiques du français. Paper presented at CILFR XXIII, Salamanca, 24-30 September.

Solimando Carbone, Antonietta (2001). Note di morfologia e sintassi nel dialetto di San Giovanni in Fiore. Unpublished Lizenziatsarbeit, University of Zurich.

Sorace, Antonella (2000). Gradients in auxiliary selection with intransitive verbs. Language 76, 859-890.

Squartini, Mario (1998). Verbal Periphrases in Romance: Aspect, Actionality and Grammaticalization. Berlin and New York: Mouton de Gruyter.

Tuttle, Edward F. (1986). The Spread of ESSE as Universal Auxiliary in Central ItaloRomance. Medioevo Romanzo 11, 229-287.

Van Valin, Robert (1990). Semantic parameters of split intransitivity. Language 66, $221-260$.

Weber Wetzel, Elena (2002). Il dialetto di Casale Corte Cerro. Contributo alla conoscenza delle parlate del Cusio. Alessandria: Edizioni dell'Orso.

Wehr, Barbara (1998). Zur Beschreibung der SE-Konstruktionen im Romanischen. In Neuere Beschreibungsmethoden der Syntax romanischer Sprachen. Wolfgang Dahmen, Günter Holtus, Johannes Kramer, Michael Metzeltin, Wolfgang Schweickard, and Otto Winckelmann (eds.), 127-148. Romanistisches Kolloquium XI. Tübingen: Narr. 